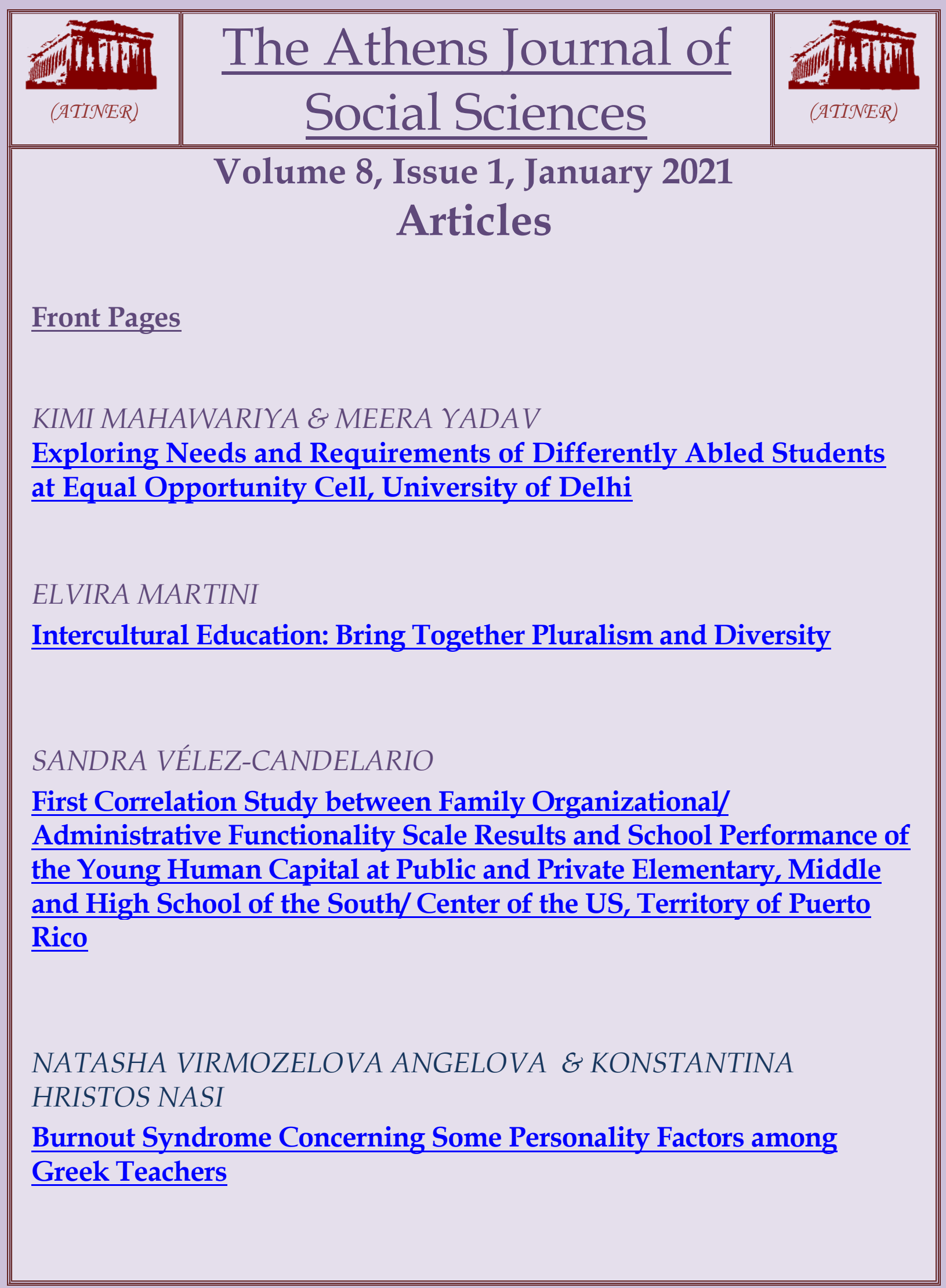




\section{Mission}

ATINER is an Athens-based World Association of Academics and Researchers based in Athens. ATINER is an independent and non-profit Association with a Mission to become a forum where Academics and Researchers from all over the world can meet in Athens, exchange ideas on their research and discuss future developments in their disciplines, as well as engage with professionals from other fields. Athens was chosen because of its long history of academic gatherings, which go back thousands of years to Plato's Academy and Aristotle's Lyceum. Both these historic places are within walking distance from ATINER's downtown offices. Since antiquity, Athens was an open city. In the words of Pericles, Athens"... is open to the world, we never expel a foreigner from learning or seeing". ("Pericles' Funeral Oration", in Thucydides, The History of the Peloponnesian War). It is ATINER's mission to revive the glory of Ancient Athens by inviting the World Academic Community to the city, to learn from each other in an environment of freedom and respect for other people's opinions and beliefs. After all, the free expression of one's opinion formed the basis for the development of democracy, and Athens was its cradle. As it turned out, the Golden Age of Athens was in fact, the Golden Age of the Western Civilization. Education and (Re)searching for the 'truth' are the pillars of any free (democratic) society. This is the reason why Education and Research are the two core words in ATINER's name. 
The Athens Journal of Social Sciences

ISSN NUMBER: 2241-7737- DOI: 10.30958/ajss

Volume 8, Issue 1, January 2021

Download the entire issue ( $\underline{\mathrm{PDF}})$

Front Pages

Exploring Needs and Requirements of Differently

Abled Students at Equal Opportunity Cell, University of Delhi

Kimi Mahawariya \& Meera Yadav

Intercultural Education: Bring Together Pluralism and

Diversity

Elvira Martini

First Correlation Study between Family Organizational/

Administrative Functionality Scale Results and School

Performance of the Young Human Capital at Public and

Private Elementary, Middle and High School of the

South/Center of the US, Territory of Puerto Rico

Sandra Vélez-Candelario

Burnout Syndrome Concerning Some Personality

Factors among Greek Teachers

Natasha Virmozelova Angelova E Konstantina Hristos Nasi 


\section{Athens Journal of Social Sciences Editorial and Reviewers' Board}

\section{Editors}

- Dr. Gregory T. Papanikos, Honorary Professor of Economics, University of Stirling, UK. (Economics)

- Dr. Christos Sakellariou, Associate Professor of Economics, Nanyang Technological University, Singapore. (Economics)

- Dr. Nikolaos I. Liodakis, Associate Professor, Wilfrid Laurier University, Canada. (Sociology)

- Dr. Domenico Maddaloni, Associate Professor, University of Salerno, Italy. (Sociology)

- Dr. Thanos Patelis, Research Scholar, Fordham University, USA. (Psychology)

- Dr. Yannis Stivachtis, Associate Professor, Jean Monnet Chair \& Director of International Studies Program, Virginia Tech - Virginia Polytechnic Institute \& State University, USA. (Political \& International Studies)

\section{Editorial Board}

1. Dr. Bettina Koch, Head, Politics \& International Affairs Research Unit, ATINER \& Associate Professor of Political Science, Virginia Polytechnic Institute and State University, USA.

2. Dr. Thanos Patelis, Head, Psychology Research Unit, ATINER \& Research Scholar, Graduate School of Education, Fordham University, USA

3. Dr. Christos Sakellariou, Vice President of Finance, ATINER \& Associate Professor of Economics, Nanyang Technological University, Singapore.

4. Dr. David Carey, Academic Member, ATINER \& Dean, College of Progressive Education \& Director of Psychology, City Colleges, Ireland.

5. Dr. Van Coufoudakis, Emeritus Professor of Political Science, Indiana University-Purdue University, USA.

6. Dr. Albert Harris, Professor Emeritus, Department of Politics, Humboldt State University, USA.

7. Dr. Asafa Jalata, Academic Member, ATINER \& Professor, Tennessee University, USA.

8. Dr. Kimberly S. Adams, Professor of Political Science, East Stroudsburg University, USA.

9. Dr. António Duarte, Professor, Faculty of Psychology, University of Lisbon, Portugal.

10. Dr. Gail Matthews, Professor, Dominican University of California, USA.

11. Dr. Giuseppe Luca De Luca Picione, Academic Member, ATINER \& Professor, University of Naples "Federico II", Italy.

12. Dr. Michael F. Shaughnessy, Professor, School of Education, Eastern New Mexico University, USA.

13. Dr. Max Stephenson, Academic Member, ATINER \& Founding Director, Virginia Tech Institute for Policy and Governance (VTIPG), USA.

14. Dr. Christopher Dreisbach, Associate Professor, Johns Hopkins University, USA.

15. Dr. Michaelene Cox, Associate Professor, Department of Politics and Government Illinois State University, USA.

16. Dr. Domenico Maddaloni, Head, Sociology Research Unit, ATINER \& Associate Professor, University of Salerno, Italy.

17. Dr. Emmanouil Mentzakis, Academic Member, ATINER \& Associate Professor, University of Southampton, UK.

18. Dr. Auke R. Leen, Assistant Professor, Leiden University, Netherlands.

19. Dr. Timothy Zeiger, Academic Member, ATINER \& Assistant Professor, Pennsylvania State University, USA.

- General Managing Editor of all ATINER's Publications: Ms. Afrodete Papanikou

- ICT Managing Editor of all ATINER's Publications: Mr. Kostas Spyropoulos

- Managing Editor of this Journal: Ms. Despina Katzoli ( $\underline{\text { bio }})$

\section{Reviewers' Board}

Click Here 


\section{President's Message}

All ATINER's publications including its e-journals are open access without any costs (submission, processing, publishing, open access paid by authors, open access paid by readers etc.) and is independent of presentations at any of the many small events (conferences, symposiums, forums, colloquiums, courses, roundtable discussions) organized by ATINER throughout the year and entail significant costs of participating. The intellectual property rights of the submitting papers remain with the author. Before you submit, please make sure your paper meets the basic academic standards, which includes proper English. Some articles will be selected from the numerous papers that have been presented at the various annual international academic conferences organized by the different divisions and units of the Athens Institute for Education and Research. The plethora of papers presented every year will enable the editorial board of each journal to select the best, and in so doing produce a top-quality academic journal. In addition to papers presented, ATINER will encourage the independent submission of papers to be evaluated for publication.

The current issue is the first of the eighth volume of the Athens Journal of Social Sciences (AJSS), published by the Social Sciences Division of ATINER.

Gregory T. Papanikos

President

ATINER 


\section{Athens Institute for Education and Research}

A World Association of Academics and Researchers

\section{$15^{\text {th }}$ Annual International Conference on Psychology \\ 24-27 May 2021, Athens, Greece}

The Psychology Unit of ATINER organizes its $1^{\text {th }}$ Annual International Conference on Psychology, 25-28 May 2021, Athens, Greece sponsored by the Athens Journal of Social Sciences. The aim of the conference is to bring together scholars and students of psychology and other related disciplines. You may participate as stream leader, presenter of one paper, chair a session or observer. Please submit a proposal using the form available (https://www.atiner.gr/ 2021/FORM-PSY.doc).

\section{Important Dates}

- Abstract Submission: 25 January 2021

- Acceptance of Abstract: 4 Weeks after Submission

- Submission of Paper: 27 April 2021

\section{Academic Member Responsible for the Conference}

- Dr. Thanos Patelis, Head, Psychology Unit of ATINER \& Research Scholar, Fordham University, USA.

\section{Social and Educational Program}

The Social Program Emphasizes the Educational Aspect of the Academic Meetings of Atiner.

- Greek Night Entertainment (This is the official dinner of the conference)

- Athens Sightseeing: Old and New-An Educational Urban Walk

- Social Dinner

- Mycenae Visit

- Exploration of the Aegean Islands

- Delphi Visit

- Ancient Corinth and Cape Sounion

More information can be found here: www.atiner.gr/social-program

\section{Conference Fees}

Conference fees vary from $400 €$ to $2000 €$ Details can be found at: https://www.atiner.gr/2019fees 


\section{Athens Institute for Education and Research}

\section{A World Association of Academics and Researchers}

\section{5 ${ }^{\text {th }}$ Annual International Conference on Sociology 3-6 May 2021, Athens, Greece}

The Sociology Unit of ATINER is organizing its 15 th Annual International Conference on Sociology, 3-6 May 2021, Athens, Greece sponsored by the Athens Journal of Social Sciences. The aim of the conference is to bring together academics and researchers from all areas of Sociology, Social Work and other related fields. Theoretical and empirical research papers will be considered. You may participate as stream leader, presenter of one paper, chair a session or observer. Please submit a proposal using the form available (https://www.atiner.gr/2021/FORM-SOC.doc).

\section{Important Dates}

- Abstract Submission: : 4 January 2021

- Acceptance of Abstract: 4 Weeks after Submission

- Submission of Paper: 5 April 2021

\section{Academic Member Responsible for the Conference}

- Dr. Domenico Maddaloni, Head, Sociology Research Unit, ATINER \& Associate Professor, University of Salerno, Italy.

- Dr. Yorgo Pasadeos, Director Social Sciences Division, ATINER \& Professor Emeritus, University of Alabama USA.

- Dr. Sharon Claire Bolton, Head, Management Research Unit, ATINER \& Professor, The Management School, University of Stirling, Scotland.

\section{Social and Educational Program}

The Social Program Emphasizes the Educational Aspect of the Academic Meetings of Atiner.

- Greek Night Entertainment (This is the official dinner of the conference)

- Athens Sightseeing: Old and New-An Educational Urban Walk

- Social Dinner

- Mycenae Visit

- Exploration of the Aegean Islands

- Delphi Visit

- Ancient Corinth and Cape Sounion

More information can be found here: https://www.atiner.gr/social-program

\section{Conference Fees}

Conference fees vary from $400 €$ to $2000 €$

Details can be found at: https:// www.atiner.gr/2019fees 


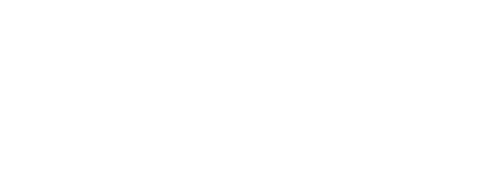




\title{
Exploring Needs and Requirements of Differently Abled Students at Equal Opportunity Cell, University of Delhi
}

\author{
By Kimi Mahawariya* $^{*}$ Meera Yadav ${ }^{\dagger}$
}

\begin{abstract}
A differently-abled student needs special attention due to his or her different learning abilities, medical condition or any physical disability. It is essential that all Institutions must put efforts to provide various facilities best suited to these students and bring about their intellectual, academic and cultural development along with all other students. The purpose of this study is to look into the various resources, facilities and services which have been provided by Equal Opportunity Cell (EOC), a special Center for specially abled students established at University of Delhi, Delhi (India) for satisfying the requirements of its users to achieve higher education. An interactive and feedback approach, by way of questionnaire and verbal interviews to reach to the opinion of the specially abled students at EOC, has been practised by the author for the study. The findings show that EOC provides some important facilities to its users such as short term courses along with sports events specially designed and organized for them, computer laboratories as per their requirements, scanning and accessible reading equipments to visually impaired students and provisions of volunteers for providing support to disable students followed with transport facilities for them. It is also observed that the staff of the EOC was very helping towards the students. Overall, students have accepted that EOC has been fulfilling its motto for creating a barrier free environment for them for their learning needs. The study recommends to quantitative increase in the numbers of assistive devices, installation of advanced Information and Communication Technology (ICT) tools and softwares for better and more efficient support to the specially-abled students.
\end{abstract}

Keywords: Equal Opportunity Cell (EOC), differently-abled students, specially abled students, Person with Disability (PwD), Physically handicapped students, University of Delhi and blind students.

\section{Introduction}

Information is combination of two aspects i.e. data and knowledge. Data is termed as meaningful information and it represents the value attributed to parameters whereas knowledge signifies understanding of the specific concept or term. In terms of communication, information is expressed as content of message or as direct or indirect observation.

A differently abled or specially abled student or learner is a student whose ability of learning is different from other students because of various reasons such

*PhD Scholar, University of Delhi, India.

${ }^{\dagger}$ Associate Professor, University of Delhi, India. 
as mental health or condition, learning disability or physical disability.

Various organizations are working to provide best possible facilities to these students which could enable them to attain higher education with least restrictions of their disabilities. Government of India has established more than forty Central Universities, i.e., funded by Central Government, in order to disseminate and advance knowledge and improve the social, economic conditions of all kinds of the people (including differently abled) and bringing about their intellectual, academic and cultural development.

University of Delhi is one of the top Central Universities which is situated in the capital of India i.e. New Delhi. An EOC was established in 2006 in University of Delhi with the motive to help and motivate special learners for their higher education needs. The Center of the University follows all the necessary instructions and guidelines issued from time to time by the Government of India (GoI). According to GoI, specialized syllabus, teaching method, teaching or learning equipment or gadgets should be adopted to enable differently abled students to get education and increase their learning abilities in a best possible way. Various other facilities should also be provided to special need students, like:

1. Physical facilities: Institution should provide special facilities to differently abled students in way to provide them opportunities to acquire quality education as well as to bring them into the main stream of society. These students should be treated as normal students and should be respected as what they are. Physical facilities like wheel chairs, blind sticks, audiorecorder, talking books and newspapers should be provided by institutions to its special need students.

2. Ramps or Rails: Institutions should have special ramps or rails for blind and physically handicapped students. Proper signals and symbols should be located, as well as main entry or exit gates should clearly be identifiable and easily be accessible. Steps and ramps should have hand railing and if possible Institutions should have an easy access facility to conveniently located lift.

3. Rest rooms: There should be separate rest rooms for special need students with clear identification and accessibility as well as large inside space. Doors of rest rooms should be wide enough with easy locking or unlocking system. Floors should be slip resistant. Mirrors, flushing arrangement and dispensers should be mounted at appropriate height.

4. Provision for Scribes: Institutes should provide and allow scribes to disabled students for examination for those having difficulty in writing examinations. Following guidelines as per GoI, should strictly be followed while appointing scribes to differently abled students:

- A blind student or physically handicapped student with writing problem or learning disabled students may select the scribe.

- An extra 1 hour's time is allowed to scribes to write examination.

- A separate room should be allotted to the disabled students with scribe so that disabled students can easily dictate and scribe; easily write under their guidance. 
- The scribe need not have a lower qualification to that of the student as well as scribe should not possess similar qualification pertaining to the examination which the student is writing. Scribe should have qualification of the similar level to the student but with different background or stream.

- Scribe should not be a relative or near relative of the student.

5. Braille Software or Facilities: Blind students can easily read and learn from Braille books and Braille software, through which they can improve and develop their language and skills. Therefore, Institutions should have Braille reading material and computer systems equipped with Braille software in their Center or library or any other reading place.

6. Other facilities: Facilities like big size audio and visual signals indicating different sections of the building should be located on different floors at arrival and other parts of building division. Lifts with wide space for wheelchair should be located near the entrance with proper parking facility inside and outside the building.

\section{Literature Review}

\section{$\underline{\text { Resources and Services for Special Need Students }}$}

Ambali et al. (2018) in their studies have assessed resources and service provisions for differently abled library users in University of Ilorin and Federal College of Education (Special), Oyo. In their research, they surveyed all disabled patrons of libraries of aforementioned Educational Institutions as sample for the investigation. The study showed that out of the total sample survey, largest percentage of the users constituted deaf students followed by dump students. The students accepted that they were more comfortable by accessing resources and services in Federal College of Education as compared to University of Ilorin.

\section{$\underline{\text { Special Provisions for Differently Abled Students }}$}

Walee (2017) has compared various types of support services that are provided to disabled students at two New Jersey Community Colleges. The study revealed various challenges such as financial problems, lack of remedial courses and awareness and self-advocacy faced by students. Petree and Wade (2018) in his participatory action research project studied for students with disabilities in a four year University system indicated requirement for a centralized community resource center for the differently abled students which could provide them with a meeting space for communicating and sharing resources with similar students. Kavishe and Isibika (2018) studied two university libraries (i.e. Ardhi University and University of Dar Es Salaam) in Tanzania to investigate the various types of provisions that have been provided for the people in wheelchairs for using library services. The results revealed that the libraries under study were not complying with the university library services to the users. Hence, it was suggested that libraries should always tried to provide the services which are accessible to all 
users including the students in wheelchairs.

\section{$\underline{\text { Utilization of Resources and Services }}$}

Babu and Xie (2017) explored the designs which were obstructing the blind users in the accessibility of digital libraries. Their study was based on interaction experiences with American Memory Digital Collection (AMDC) users. It was observed that the AMDC is not user friendly. Accordingly, they have tried to create awareness with regard to various choices of designs that could help blind students for seeking information from the digital libraries.

\section{Problems Faced by Disabled Students and Staff}

Heyer (2017) has found that there are varieties of problems and challenges that are being faced by disabled students as compared to normal students in their day to day learning. The study was based on the students entering or enrolled in Santiago Canyon College, Orange, California. Researcher concluded that it's not just a matter of providing grant proposals to the differently abled students for their higher education students rather the students should be empowered so that they can become their own advocates. Hence, a training program which could empower differently abled students to overcome their hurdles and to know their capabilities would more efficiently help them in pursuing their higher education.

\section{$\underline{\text { Needs and Requirements of Special Need Students }}$}

Rayini (2017) while taking into account the guidelines issued by IFLA, Government of India and University Grants Commission (India) has opined that the blind students also have the same needs and requirements for seeking information as sighted students. It has also been stated that the visually impaired students also need that the required information may be accessed in their chosen format. He has described the barriers being faced by the blind students for seeking their information resources and has emphasized on utilizing IT tools and following the suggested guideline for improving the accessibility of library and information services to the blind students.

\section{Statement of Problem}

The present study was undertaken to explore a less researched area which require researchers' attention and focus so that the special need students and their service providers, can both be benefitted.

\section{Objectives of the Study}

In this study, users as well as managers of EOC, University of Delhi, India were surveyed to: 
- Know types and kinds of resources and services provided by EOC for the special need students.

- Find out various special provisions available to differently abled students in EOC.

- Observe purpose of visiting EOC and motive of utilization of resources in EOC.

- Analyze usability of different resources and services by the students at EOC.

- Identify satisfaction level of students with the resources, services and staff of the Center.

- Observe worthiness of special provisions to differently abled students of EOC.

- Find out problems faced by staff while serving differently abled students and the problems faced by the student themselves while utilizing information resources at EOC.

- Know any other need or requirement of the differently abled students.

\section{Research Methodology}

Study Design

The broad area of the study is to know the information about the collection, services, infrastructural facilities and other ICT tools and technologies available and their usability at EOC. Both the qualitative as well as quantitative approaches have been considered appropriate for this study as the need or target of the investigators were to get the aforementioned information not just by going through the figures that are available on record of EOC but to cross-check them by experience, knowledge, thinking and perception of staff and the user students at EOC. The study has basically focused on exploring needs and requirements of differently abled students, the facilities being provided to them and the most important aspect that what are the areas of improvements to the present scenario at EOC based on the requirements of the students.

\section{Participants}

The Head and other related staff of EOC were purposely selected to serve as focused source of information for this study. However, in line with data collection method, investigators have interacted with many students (out of which only 63 students were able to participate in the research study) to bring clarity on the facts, figures and information provided by the staff of EOC and also to know usability pattern of the resources and services available at EOC.

\section{Data Collection Methods}

Data was gathered through Questionnaire, semi-structured interviews and participant observations. 


\section{Questionnaire}

A survey research is the collection of information from a sample of individuals through their responses to questions (Check and Schutt 2012). After a deep review of the available literature on various aspects related to differently abled students, two questionnaires were prepared to collect data. First questionnaire was focused to get information from Head/Staff of the EOC about the availability of collection, resources, services, facilities and the ICT tools and technologies in the centre for differently abled students. Second questionnaire was prepared to get information from the users of the EOC with the focus to know users' point of view on available resources and services at EOC, usability pattern and problems faced by them.

\section{$\underline{\text { Semi-structured Interview }}$}

Apart from getting data with the help of questionnaires, the author also personally interacted with the staff and users of the EOC for overall help in the research and to get information which participants do not want highlight in the questionnaires. Data collection from blind students has been through interview basis wherein the author do dictate all the questions to them and recorded their responses.

\section{Participant Observation}

This study is an interactive social process. Thus it is only by taking a practical observation of events that one can obtain a comprehensive understanding of the case being studied (deMarrais and Lapan 2004, Simons 2009).

This study focuses on different special need students and undertaking a practical observation only can help in comprehensive understanding of the use and worth of available resources and services at EOC.

\section{Data Analysis}

Data analysis was done in tabulated form with the responses retrieved from questionnaires, interviews and observation.

\section{Findings}

The present study consists of following two fold surveys:

1. Observation and analysis on availability of information resources and services at EOC: The first part of the study was to find out availability of information resources and services to the differently abled students. For this, the Investigator has had interactive experience with the Head and other staff of the EOC. 
2. Observation and analysis on user perspective on the usability of available information resources and services at EOC: The second aspect of the study was to analyze the validity and reliability of the information retrieved from the provider of the services and resources. This was achieved through recording responses of the users of the EOC in the user oriented questionnaire as well as through verbal interactions.

\section{Availability of Information Resources and Services}

The information retrieved from the Head of the Cell and other staff regarding the facilities and services at EOC, University of Delhi has been discussed and interpreted in the tables mentioned below.

\section{Collection of EOC for Differently Abled Students}

EOC is well known in terms of services it provides to its users. It is well equipped with special collection for differently abled students. A list of various special collections and information of its availability in EOC are given below:

Table 1. Collection of EOC

\begin{tabular}{|l|c|c|}
\hline $\begin{array}{l}\text { Serial } \\
\text { Number }\end{array}$ & Information Resources & Yes or No \\
\hline 1 & Braille Books & Yes \\
\hline 2 & Braille Software & Yes \\
\hline 3 & Audio or Talking Books & Yes \\
\hline 4 & Talking Newspapers & Yes \\
\hline 5 & Recorded reading material & Yes \\
\hline 6 & Assistive Technologies & Yes \\
\hline 7 & Large Printed material & Yes \\
\hline 8 & Soft copy e-text & Yes \\
\hline 10 & Scanned books in text & No \\
\hline 11 & $\begin{array}{r}\text { Books in electronic publishing format } \\
\text { through outsourcing agency }\end{array}$ & Yes \\
\hline 12 & Scanned magazines & \\
\hline
\end{tabular}

As depicted in Table 1 above, it was found that EOC has 3 audio book production studios, 2 high capacity Braille embossers and it has most of the specialized collection like 1,885 Braille books, 1,755 talking books, various Large printed material for low vision students, 1,694 Softcopy e-text and various books scanned in digital accessible information system. The Center also possesses assistive technologies to fulfill user's required information needs. EOC does not have Scanned magazines and E-books from outsourcing agencies. 


\section{Physical Equipments or Infrastructure Facility to Special Need Students}

To assist users with the resources of the EOC, it must have a good infrastructure as well as required equipments for the smooth functioning of the same. Availability of various infrastructural facilities and physical equipments available in the EOC are tabulated in Table 2.

Table 2. Physical Equipments or Infrastructure Facility

\begin{tabular}{|l|c|c|}
\hline $\begin{array}{l}\text { Serial } \\
\text { Number }\end{array}$ & Equipments & Yes or No \\
\hline 1 & Voice recorders & Yes \\
\hline 2 & Special computers & Yes \\
\hline 3 & Portal Scanners & Yes \\
\hline 4 & Magnifiers & Yes \\
\hline 5 & CD or DVD players & Yes \\
\hline 6 & Mobile Phones & Yes \\
\hline 7 & Customized Keyboards & Yes \\
\hline 8 & Blind Sticks & Yes \\
\hline 9 & Ramps and Rails & Yes \\
\hline 10 & Wheelchairs & Yes \\
\hline 11 & Transport Facility & Yes \\
\hline 12 & Separate Toilets or Rest Rooms & Yes \\
\hline 13 & Access to a conveniently located lifts & Yes \\
\hline 14 & Visual and audible signals for directions or resources & No \\
\hline
\end{tabular}

EOC has almost all the listed equipments and infrastructure except audio signal boards which help it to serve differently abled students in a better way. Equipments like voice recorders, special screen computers, and magnifiers are used by special need students for their studies. EOC also provides mobile phones, Blind sticks, and wheelchairs to the needful students for their personal use as gifts and support facilities. EOC has good infrastructure facilities available in its building to serve its users better, like it not only has ramps and railing but it also has connecting Braille library and central library with lift facility. Students don't have to go here and there for their work but they just have to reach EOC and the building has internal connectivity with the other two important libraries.

\section{Assistive Equipments Available in EOC to Provide Services in an Effective Way}

Differently abled students need alternative formats to access information resources to fulfill their information needs. The following table highlights the alternative formats or assistive equipments being provided by EOC to its users.

Table 3 reveals that EOC acquires only 50\% (10) assistive equipments out of 20 listed above and these include screen magnifiers, Braille printers, Cleat reader and Heavy lenses. Thus, Center is lacking in acquiring adequate assistive equipments, therefore it will be quite difficult for special need students specially visually impaired students to use EOC material for their study purposes because they can use resources only with the help of assistive devices or alternate format. Hence, there is a need of such type of equipments in EOC to cater the needs of 
these users.

Table 3. Assistive Equipments Available in EOC

\begin{tabular}{|l|c|c|}
\hline $\begin{array}{l}\text { Serial } \\
\text { Number }\end{array}$ & Equipments & Yes or No \\
\hline 1 & Screen Magnifiers & Yes \\
\hline 2 & Braille Printers & Yes \\
\hline 3 & Hand-held Scanners & Yes \\
\hline 4 & Magnifying Glasses & Yes \\
\hline 5 & One hand keyboards & Yes \\
\hline 6 & Refresher able Braille display & Yes \\
\hline 7 & Cleat readers & Yes \\
\hline 8 & Large print keyboards & Yes \\
\hline 9 & Rssistive listening device conversers & Yes \\
\hline 10 & Eye-C Handheld Video magnifiers & No \\
\hline 11 & Keyboard Overlay & No \\
\hline 12 & Braille Typewriters & No \\
\hline 13 & Talking Scientific Calculators & No \\
\hline 14 & Flatbed Scanners & No \\
\hline 15 & Overhead scanners & No \\
\hline 16 & Sonic guides & No \\
\hline 17 & Voice eyes & No \\
\hline 18 & Ruby visual studio code & No \\
\hline 19 & Heavy lenses & No \\
\hline 20 & & Yes \\
\hline
\end{tabular}

Special Services Provided by EOC to Differently Abled Students

Table 4. Special Services to Differently Abled Students

\begin{tabular}{|l|c|c|}
\hline $\begin{array}{l}\text { Serial } \\
\text { Number }\end{array}$ & Services & Yes or No \\
\hline 1 & $\begin{array}{c}\text { Current Awareness Services (CAS) and Selective } \\
\text { Dissemination Information (SDI) }\end{array}$ & Yes \\
\hline 2 & Online databases & Yes \\
\hline 3 & E-Document Delivery Services (EDDS) & Yes \\
\hline 4 & E-indexing and Abstracting Services & Yes \\
\hline 5 & Translation Services & Yes \\
\hline 6 & Reference Services & Yes \\
\hline 7 & Newspaper Clipping & No \\
\hline 8 & Transcription Services & Yes \\
\hline 9 & Braille Translation & No \\
\hline 10 & Internet Facility & Yes \\
\hline 11 & Screen reading enabled library catalogue & Yes \\
\hline 12 & Online Public Access Catalogue (OPAC) & Yes \\
\hline 13 & Special Courses & Yes \\
\hline 14 & Scribe for examination & Volunteers or Helpers \\
\hline 15 & &
\end{tabular}


There is a need of special services in any educational institution to serve special need students. Table 4 has highlighted various special services and facilities available to differently abled students.

Results of Table 4 above reveals that EOC provides almost all special services and facilities to its special need students except Screen reading enabled library catalogue and transcription services. EOC provides services like CAS, SDI, EDDS, E-indexing and abstracting services, Braille translation, OPAC, as well as special courses on subjects such as Information and Communication Technology, Communicative English (Basic and Advance Level), Disability and Human Rights, and Sign Language Interpretation (Level A and B) to special need students to make them more skilled and trained. Besides, EOC also organizes Sports events for physically handicapped students.

\section{E-resources or Assistive Software for Special Need Students in EOC}

Table 5. E-resources or Assistive Softwares for Special Need Students

\begin{tabular}{|c|c|c|}
\hline $\begin{array}{c}\text { Serial } \\
\text { Number }\end{array}$ & E-resources & Yes or No \\
\hline 1 & JAWs Pro Talking Softwares & Yes \\
\hline 2 & Kurzweil 1000 OCR Reading Softwares Pro. & Yes \\
\hline 3 & Braille Scanning Software-OBR & Yes \\
\hline 4 & Angle, Pro & Yes \\
\hline 5 & Freedom Scanning SARA & No \\
\hline 6 & Zoom-X & No \\
\hline 7 & NVDA Software & Yes \\
\hline 8 & LEX Cam scanner & No \\
\hline 9 & Speech Synthesis & No \\
\hline 10 & Digital Voice recorder ICU-UX70 & No \\
\hline 11 & Talk and Zoom & Yes \\
\hline 12 & Talk Backs & No \\
\hline 13 & Hindi OCR & Yes \\
\hline 14 & OBI DAISY & Yes \\
\hline 15 & SAFA Reader & No \\
\hline 16 & Open Book & No \\
\hline 17 & Read Easy & No \\
\hline 18 & Lasecann & No \\
\hline 19 & AMIS & No \\
\hline 20 & Pearl Instant Reader & No \\
\hline 21 & ABBYY fine reader & No \\
\hline 22 & Vaachak & No \\
\hline 23 & Magic Pro Magnification & Yes \\
\hline 24 & Dux Bury & Yes \\
\hline 25 & Talking Typing Teacher Pro & $\mathrm{No}$ \\
\hline 26 & Infity reader and Chatty Infity & $\mathrm{No}$ \\
\hline 27 & Sparsha & Yes \\
\hline 28 & PUTTY & Yes \\
\hline 29 & Sigtuna & Yes \\
\hline 30 & Leap Office & Yes \\
\hline
\end{tabular}


Educational Institutions must arrange tools and resources as per the requirements of disabled users and should offer a variety of services for students with special needs. The term 'special needs' in terms of library and information services relates to the needs of people who are not able to use standard library and information services. In this regard professionals of EOC were asked about the software available for differently abled students and the availability is shown in Table 5 .

It is found that EOC has network of 22 latest computers with softwares like Daisy System, Sparsha, OBI, PUTTY, Sigtuna, Jaw, Duxbury, Leap Office, NVDA software, Hindi OCR, Magic Pro Magnification, and Kurzweil 100 OCR Reading software.

\section{Problems Faced by Staff of EOC While Serving PwD Students}

Table 6 ascertains the difficulties encountered by EOC's staff in providing services to special need students.

Table 6. Problems Faced by Staff

\begin{tabular}{|l|c|c|}
\hline $\begin{array}{l}\text { Serial } \\
\text { Number }\end{array}$ & Problems & Yes or No \\
\hline 1 & Lack of funds & No \\
\hline 2 & Untrained Staff to deliver services & Yes \\
\hline 3 & Sustainable equipments & No \\
\hline 4 & Users attitude & No \\
\hline 5 & Maintenance of assistive software and equipments & No \\
\hline 6 & Unstandardized open access resources & No \\
\hline 7 & Less number of resources compliant with standards & No \\
\hline 8 & Lack of cooperation with authorities & No \\
\hline 9 & Scanning process consumes time & Yes \\
\hline 10 & Dissemination of information & No \\
\hline 11 & Poor internet connectivity & Yes \\
\hline 12 & Lack of awareness about ICT among users & Yes \\
\hline 13 & Lack of active volunteers & Yes \\
\hline
\end{tabular}

Table 6 reveals various problems encountered by staff of EOC in serving special need students. The problems mentioned by them are poor internet connectivity, lack of awareness about ICT among users, time consumption in scanning, and availability of few untrained staff.

\section{User Perspective on the Information Resources and Services}

After interacting with staff and Head of EOC, investigators interacted with users of the cell to have a real impression of resources and services provided by the EOC on differently abled students. To ensure objectivity and validity in the research, the investigator distributed 100 choice based questionnaires to the users of the EOC who are differently abled students. Only 63 percent response could be recorded from the user students because of various limitations such as lack of time, 
patience and interest. The responses of users so recorded have been analyzed and the perspective of users is depicted in Table 7.

\section{Types of Users Who Visit EOC}

The EOC is effectively taking steps to implement the provisions of the Rights of Persons with Disabilities Act, 2016, particularly in admissions. More than 5,500 students with special need get enrolled in various disciplines under University of Delhi. The different kinds of visitors at EOC are tabulated as in Table 7.

Table 7. Types of Users

\begin{tabular}{|l|c|c|c|}
\hline $\begin{array}{l}\text { Serial } \\
\text { Number }\end{array}$ & Particulars & No. of students & Percentage \\
\hline 1 & Students with visual disability & 40 & 63.49 \\
\hline 2 & Students with Hearing disability & 3 & 4.76 \\
\hline 3 & Students with physical disability & 19 & 30.15 \\
\hline 4 & Students with Mental disability & 0 & 0 \\
\hline 5 & $\begin{array}{c}\text { Others (students with speech } \\
\text { disability or other disability) }\end{array}$ & 1 & 1.58 \\
\hline & Total & $\mathbf{6 3}$ & $\mathbf{1 0 0}$ \\
\hline
\end{tabular}

It is observed from the data collected that approximately 50 students visit EOC on daily basis to utilize its resources and services. Table 7 shows that around $64 \%$ students visiting EOC are observed to be visual impaired students. Investigator had not observed any student with mental disability at EOC. Only $1.58 \%$ students with speech problem or any other minor disability were observed to be visiting at EOC.

\section{Purpose of Seeking Information from the Institute}

Each individual has different purpose to use library resources. Investigator asked differently abled students about their purpose of using information resources of Equal Opportunity Cell. The findings have been depicted in Table 8.

Table 8. Purpose of Seeking Information

\begin{tabular}{|l|c|c|c|}
\hline $\begin{array}{l}\text { Serial } \\
\text { Number }\end{array}$ & Purposes & No of Students & Percentage \\
\hline 1 & Class notes & 30 & 47.61 \\
\hline 2 & General Awareness & 24 & 38.09 \\
\hline 3 & Knowledge Update & 24 & 38.09 \\
\hline 4 & Research & 12 & 19.04 \\
\hline 5 & Any Other & 6 & 9.52 \\
\hline & Total & $\mathbf{9 6}$ & - \\
\hline
\end{tabular}

Note: Multiple choices were allowed.

It is observed that students are giving much more importance to class notes and curriculum related studies (48\% approximately). EOC helps differently abled 
students for providing them notes of different subjects on different topics in different formats, e.g., notes in recorded format provided to blind or low vision students. Students were also using the cell for boosting their general awareness (38\% approximately) and updating their subject knowledge (38\% approximately) required for clearing various competitive examinations related to career and other academic prospects. Besides, students were making use of the resources at EOC for research purposes, knowledge update and other requirements.

\section{Types of Resources used by Differently Abled Students}

Investigators surveyed students to know about type of library and information resources used by them. The result showed that most of the students still prefer traditional information resources in print media form. It has also been noticed that blind students preferred audio resource. The findings are tabulated in Table 9.

Table 9. Type of Resources

\begin{tabular}{|l|c|c|c|}
\hline $\begin{array}{l}\text { Serial } \\
\text { Number }\end{array}$ & Resource Type & No of Students & Percentage \\
\hline 1 & Print & 51 & 80.95 \\
\hline 2 & E-Resources & 6 & 9.52 \\
\hline 3 & Audio-Video & 30 & 47.61 \\
\hline 4 & Reference Collection & 6 & 9.52 \\
\hline 5 & Internet & 21 & 33.33 \\
\hline 6 & Any Other & 3 & 4.76 \\
\hline & Total & $\mathbf{1 1 7}$ & - \\
\hline
\end{tabular}

Note: Multiple choices were allowed.

It was observed from Table9 that around $81 \%$ students prefer print resources over e-resources. Only few students (around 10\%) visit EOC for reference collection and e-resources. Apart from this, around 50\% students utilize audio or visual resources.

\section{Satisfaction Level with Overall Collection of the Center}

Investigator tried to find out effectiveness of collection of information resources in EOC, so differently abled students were surveyed about their point of view on collection available in the Center. Findings are highlighted in the Table 10.

As per the findings, out of 63 students 27 (around 43\%) students were extremely satisfied with the overall collection of the books in the center. Hence, the center is trying hard to meet the needs and requirements of its users. 
Table 10. Satisfaction Level with Overall Collection

\begin{tabular}{|l|c|c|c|}
\hline $\begin{array}{l}\text { Serial } \\
\text { Number }\end{array}$ & Particulars & No of Students & Percentage \\
\hline 1 & Extremely Satisfied & 27 & 42.85 \\
\hline 2 & Satisfied & 24 & 38.09 \\
\hline 3 & Unsatisfied & 3 & 4.76 \\
\hline 4 & Extremely unsatisfied & 6 & 9.52 \\
\hline 5 & Can't say & 3 & 4.76 \\
\hline & Total & $\mathbf{6 3}$ & $\mathbf{1 0 0}$ \\
\hline
\end{tabular}

Sources Referred By Users to Get Information from Online Resources or Offline Resources

Both online and offline resources are very important to learn anything in a better way. Both of these resources are preferred and utilized by users of EOC because of their respective benefits. Users were surveyed about the sources used by them to utilize online as well as offline resources (Table 11a, 11b).

Table 11a. Online Resources

\begin{tabular}{|l|c|c|c|}
\hline $\begin{array}{l}\text { Serial } \\
\text { Number }\end{array}$ & Particulars & No of Students & Percentage \\
\hline 1 & Website & 39 & 61.90 \\
\hline 2 & E-Journals & 9 & 14.28 \\
\hline 3 & E Mail & 6 & 9.52 \\
\hline 4 & E Database & 15 & 23.80 \\
\hline 5 & Any Other & 0 & 0 \\
\hline & Total & $\mathbf{6 9}$ & - \\
\hline
\end{tabular}

Note: Multiple choices were allowed.

It is observed that students are using online resources to get the relevant information. Through online resources, students visit Website (62\% approximately) to get the relevant information. E Database (24\% approximately) and E-journals (14\% approximately) are also being used by the students.

Table 11b. Offline Resources

\begin{tabular}{|l|c|c|c|}
\hline $\begin{array}{l}\text { Serial } \\
\text { Number }\end{array}$ & Particulars & No of Students & Percentage \\
\hline 1 & Books & 25 & 39.68 \\
\hline 2 & CDs or DVDs & 10 & 15.87 \\
\hline 3 & Print Journals & 16 & 25.39 \\
\hline 4 & Any Other reference sources & 12 & 19.04 \\
\hline & Total & $\mathbf{6 3}$ & $\mathbf{1 0 0}$ \\
\hline
\end{tabular}

Offline resources are not in much use as information is always changing and they don't provide updated information. However, books are the most Preferred sources of offline resources as suggested by $40 \%$ respondents. Other forms of offline resources include CDs or DVDs (16\% approximately) and Print Journals (approximately 25\%). 
Usability of Special Provision or Facilities Provided by EOC to Differently Abled Students

Special need students need special attention so that their needs and requirement can be fulfilled easily. EOC provides various special facilities to them but their effectiveness can only be validate with the responses of the users, so investigator surveyed users about facilities available to them. The responses are tabulated in Table 12.

Table 12. Special Provision or Facilities

\begin{tabular}{|l|c|c|c|}
\hline $\begin{array}{l}\text { Serial } \\
\text { Number }\end{array}$ & Particulars & No of Students & Percentage \\
\hline 1 & Wheel Chair Facility & 3 & 4.76 \\
\hline 2 & Special facility of Ramp or Rails & 30 & 47.61 \\
\hline 3 & Access to a conveniently located lifts & 0 & 0 \\
\hline 4 & Separate Toilets or Rest Rooms & 0 & 0 \\
\hline 5 & Scribe for Examinations & 6 & 9.52 \\
\hline 6 & Braille Software or facilities & 15 & 23.80 \\
\hline 7 & $\begin{array}{c}\text { Visual and audible signals for } \\
\text { directions and resources }\end{array}$ & 12 & 19.04 \\
\hline 8 & Any Other & 0 & 0 \\
\hline & Total & $\mathbf{6 6}$ & - \\
\hline
\end{tabular}

Note: Multiple choices were allowed.

It is observed (Table 12) that students make use of special facilities available for them in the EOC like special ramps or rails (48\% approximately), scribes for examinations $(9.5 \%)$, Braille software (24\% approximately) and audio or visual signals (19\% approximately). Facility of lifts and separate toilet are available in the central library attached to EOC which is somehow utilized by users only when they access library.

Satisfaction Level with Services Provided by EOC

Investigators surveyed users about satisfaction level with services being provided by EOC to them and results are shown in Table 13.

Table 13. Satisfaction Level with Services

\begin{tabular}{|l|c|c|c|}
\hline $\begin{array}{l}\text { Serial } \\
\text { Number }\end{array}$ & Responses & No of Students & Percentage \\
\hline 1 & Extremely Satisfied & 30 & 47.61 \\
\hline 2 & Satisfied & 15 & 23.80 \\
\hline 3 & Unsatisfied & 10 & 15.87 \\
\hline 4 & Extremely unsatisfied & 7 & 11.11 \\
\hline 5 & Can't say & 1 & 1.58 \\
\hline & Total & $\mathbf{6 3}$ & $\mathbf{1 0 0}$ \\
\hline
\end{tabular}

It is observed (Table 13) that around 50\% students are extremely satisfied with the services provided by the institute but around $16 \%$ students are unsatisfied 
with the services followed with $11 \%$ users who are extremely unsatisfied with the services available in EOC, which shows that Center should update the current services.

\section{Co-operation of Staff with Special Need Students While Accessing Resources}

Along with useful collection and effective services, it is also of a great importance to have skilled and hardworking staff to serve the users in an effective way. Hence cooperation of the Staff is an essential element for the special need students while accessing the resources at any Center. Students were surveyed about cooperation of staff with them and findings are presented below.

Table 14a. Cooperation of Staff

\begin{tabular}{|l|c|c|c|}
\hline $\begin{array}{l}\text { Serial } \\
\text { Number }\end{array}$ & Responses & No of Students & Percentage \\
\hline 1 & Yes & 46 & 73.01 \\
\hline 2 & No & 17 & 26.98 \\
\hline & Total & $\mathbf{6 3}$ & $\mathbf{1 0 0}$ \\
\hline
\end{tabular}

It is observed (Table 14a) that out of 63 students, 46 students have expressed that the staff was co-operative and fully able to solve their problems. However, 17 students were not satisfied with the staff.

If No: Reasons for the same

Table 14b. Reasons for Dissatisfaction

\begin{tabular}{|l|c|c|c|}
\hline $\begin{array}{l}\text { Serial } \\
\text { Number }\end{array}$ & Reasons & No of Students & Percentage \\
\hline 1 & Staff is unwilling to serve & 0 & 0 \\
\hline 2 & Lack of awareness of staff & 8 & 47.05 \\
\hline 3 & Lack of skilled staff & 3 & 17.64 \\
\hline 4 & No special provision to treat you & 6 & 35.29 \\
\hline 5 & Any Other & 0 & 0 \\
\hline \multicolumn{2}{|c|}{ Total } & $\mathbf{2 7}$ & - \\
\hline
\end{tabular}

Note: Multiple choices were allowed.

The students (as mentioned in Table 14b), who have expressed that staff was not co-operative towards them, have informed that there was lack of awareness among the staff and there was no special provision to assist or help them.

\section{Users' Approach to Retrieve Information from the Center}

There can be various methods through which the user enables himself or herself to retrieve the information from any particular center. It is important to know whether the Center is capable of making its user confident of retrieving information through themselves by the possible and available services and if not so, then what are the other available modes for them. Hence, the investigator 
interviewed users of EOC to find about their approaches to retrieve the requisite information. The observations are mentioned in Table 15.

Table 15. Modes of Retrieval of Information

\begin{tabular}{|l|c|c|c|}
\hline $\begin{array}{l}\text { Serial } \\
\text { Number }\end{array}$ & Responses & $\begin{array}{c}\text { No of } \\
\text { Students }\end{array}$ & Percentage \\
\hline 1 & Yourself & 15 & 23.80 \\
\hline 2 & With the help of staff & 30 & 47.61 \\
\hline 3 & With the help of other students & 12 & 19.04 \\
\hline 4 & Any special staff appointed to help you & 3 & 4.76 \\
\hline 5 & Any person brought by you & 5 & 7.93 \\
\hline \multicolumn{2}{|c|}{ Total } & $\mathbf{6 5}$ & $\mathbf{1 0 0}$ \\
\hline
\end{tabular}

Note: Multiple choices were allowed.

It is observed from the users' responses (showed in Table 15) that students at EOC retrieve information with the help of staff (46\%), by themselves (23\%), with the help of other students (18\%), any other external assistant brought by them $(8 \%)$ and also with the help of any special library staff (5\%). Hence, majority of the students are dependent on the staff of EOC.

Problems Faced by the Students While Retrieving Information Resources and Services from $E O C$

Although the Center has been taking effective measures to serve its users, however, it is important to know the problems of the students while accessing and retrieving information resources at the EOC. Accordingly, the Investigator surveyed users about those problems and the observations are mentioned in Table 16.

Table 16. Problems Faced by Users

\begin{tabular}{|l|c|c|c|}
\hline $\begin{array}{l}\text { Serial } \\
\text { Number }\end{array}$ & Particulars & $\begin{array}{c}\text { No of } \\
\text { Students }\end{array}$ & Percentage \\
\hline 1 & Unavailability of required information & 24 & 38.09 \\
\hline 2 & Staff is not willing to serve & 18 & 28.57 \\
\hline 3 & $\begin{array}{c}\text { Information retrieval process is time } \\
\text { consuming }\end{array}$ & 21 & 33.33 \\
\hline 4 & Absence of adequate guides in the library & 18 & 28.57 \\
\hline 5 & Information is not well managed & 9 & 14.28 \\
\hline 6 & Lack of awareness of staff & 21 & 33.33 \\
\hline 7 & Old technology used by center & 12 & 19.04 \\
\hline 8 & Poor Internet & 13 & 20.63 \\
\hline 9 & Timing of circulation & 10 & 15.87 \\
\hline 10 & Time consumed in circulation & 10 & 15.87 \\
\hline 11 & Lack of adequate helpers in center & 5 & 7.93 \\
\hline 12 & Any Other & 0 & 0 \\
\hline & Total & $\mathbf{1 6 1}$ & - \\
\hline
\end{tabular}

Note: Multiple choices were allowed. 
Students, inter-alia, mentioned (in Table 16 above) various problems such as Unavailability of required information (38\%), Lack of awareness of staff (33\%), information retrieval process is time consuming (33\%), Staff not willing to serve (28\%), Absence of adequate guides in the Center (28\%), internet problem (21\%), Old technology used by the Center (19\%), circulation related problems $(16 \%)$ that were affecting them.

\section{Areas which need to be improved in EOC according to Users}

Investigator has further asked users as to whether they need any changes in the functionality of the Center or any particular area which need updating. The results obtained are presented below:

Table 17. Areas of Improvement in EOC

\begin{tabular}{|l|c|c|c|}
\hline $\begin{array}{l}\text { Serial } \\
\text { Number }\end{array}$ & Particulars & $\begin{array}{c}\text { No of } \\
\text { Students }\end{array}$ & Percentage \\
\hline 1 & More Helpers should be appointed & 7 & 11.11 \\
\hline 2 & More space to sit or walk & 4 & 6.34 \\
\hline 3 & $\begin{array}{c}\text { More ICT facilities and services according } \\
\text { to your needs }\end{array}$ & 10 & 15.87 \\
\hline 4 & More equipments of reading and writing & 15 & 23.80 \\
\hline 5 & $\begin{array}{c}\text { Need of more collection according to your } \\
\text { needs }\end{array}$ & 8 & 12.69 \\
\hline & Total & $\mathbf{4 4}$ & - \\
\hline
\end{tabular}

Note: Multiple choices were allowed.

Majority of the differently abled students have requested for increasing the reading and writing equipments in the center (24\%). Provisions of more helpers, more equipments, ICT facilities, better place to sit or walk are other areas of improvements. It was also observed that differently abled students also require assistance in writing their examinations and helpers to help them in walking.

\section{Discussion}

Equal Opportunity Cell established in University of Delhi has been ensuring its motive of non-discrimination for person with disabilities (PwD) students by creating a barrier free environment for them in the University. This Cell has been striving to perform its duties and fulfill its assigned responsibilities towards society.

\section{Resources and Services for Special Need Students}

It is observed that EOC is well equipped with special collection which includes Braille Books, Braille Software, Audio or Talking Books, Recorded reading material and Assistive Technologies for meeting the needs of differently abled students. 


\section{Special Provisions for Differently Abled Students}

The special services and facilities like special courses, scribes for examination, organizing sports events to them and other special library services offered by the EOC have also been praised by the user students $(72 \%$ users are satisfied with services of the cell). EOC has been taking other affirmative action in favor of PwD students like providing assistance in establishing enabling units in Colleges and sensitize University community about the PwDs. Each and every college associated to Delhi University has been instructed to provide facilities to differently abled students by establishing separate enabling cell to them, so that graduate students can be benefited at their own respective colleges. These enabling units are providing with funding and other facilities by EOC.

Sport events and competitions are some other facilities which not only raise or improve morale of the students but also motivate them to enhance their sporting or any extra- curricular skill and explore a different area to grow.

EOC has also been organizing various international visits under collaborative program for giving its students a significant learning experience and international exposure to advanced learning methods.

\section{Utilization of Resources and Services and Satisfaction Level of the Users}

The study has revealed that about $81 \%$ of the users are satisfied with the collection of EOC. Further, it is evident from the responses of the students (57\% users) that the staff at EOC is skilled, helpful and cooperative towards the users.

\section{Problems Faced by Disabled Students and Staff}

It is observed that some of the problems being faced by the users at EOC are unavailability of required information (38\%), lack of awareness of the staff (33\%) and time constraint for retrieving information (33\%).

\section{Needs and Requirements of Special Need Students}

It has also been observed that although EOC has been putting its best efforts to fulfill the needs of the students, however, there is still a scope of improvement in some areas. The students have responded that there should be increase in number of helpers (around 11\% users) and transport facilities. The students (around $16 \%$ users) have urged that the assistive devices and softwares being provided to them should be upgraded.

\section{Conclusions}

It is a moral obligation of all the libraries that the information may be made available to all kind of users irrespective of their gender, age, race, political affiliation or any kind of disability. It is also the right of the disabled students that 
they may also utilize the resources and services provided by the libraries in their own chosen format to fulfill their needs for education and learning as their counterparts do. EOC established at University of Delhi is a special center which provides required support system to the students with disabilities for their educational and social upliftment. It focuses on enabling the differently abled students to achieve their academic goals. EOC is effectively helping in creating a barrier free environment for these special learners by way of various facilities and assistive measures specially designed for the differently abled students and it should further update itself as per the present needs and requirement of its user as well as changing digital environment.

\section{Recommendations}

The study makes the following recommendations to the EOC and all other libraries:

1. It is required that libraries should install the most advance assistive devices, tools and softwares so that the users can be benefitted more effectively. Libraries should always strive to bring out the utilization of the most efficient IT tools which could be a boon for the users including the students with disabilities.

2. There should be user-oriented training programs which should be organized by respective Institutions for the students with disabilities to overcome the fear of technology and get adapted to the hassle free, time saving and user friendliness advantages of the IT tools. Staff should also be trained so that they can easily handle the users and the resources of the Institute.

3. Educational Institutions should always focus to empower the students with disabilities by looking after their needs and requirements and without their segregation, isolation and marginalizing their interests.

\section{Acknowledgments}

The authors are grateful to the competent authority of EOC for assisting this research through their special objects and devices, discrete reading material and other forms of information. The authors are also very grateful to the Indian Council of Social Science Research (ICSSR) for providing financial assistance to the presenter to attend the conference and present this study to the research community. 


\section{References}

Ambali OZ, Usman AS, Olabisi FA (2018) An assessment of the resources and services provision for the disabled library users in University of Ilorin and Federal College of Education (Special) Oyo. Library Philosophy and Practice (ejournal), 1818. https:// digitalcommons.unl.edu/libphilprac/1818.

Babu R, Xie I (2017) Haze in the digital library: design issues hampering accessibility for blind users. The Electronic Library 35(5): 1052-1065.

Check J, Schutt RK (2012) Research methods in publications. Thousand Oaks, CA: Sage Publications.

deMarrais K, Lapan SD (2004) Foundations for research: Methods of inquiry in education and the social sciences. Mahwah: Lawrence Erlbaum Associates, Inc. Publishers.

Equal Opportunity Cell. Retrieved from https://bit.ly/2uhkI7c.

Heyer C (2017) Advocacy Services for college students with disabilities: a grant proposal. California State University, Long Beach, Ann Arbor.

Kavishe GF, Isibika IS (2018) Provision of library services for users in Wheelchairs at Ardhi University and University of Dar Es Salaam Libraries. Library Philosophy and Practice (e-journal): 1-11. Retrieved from https://bit.ly/2YxVRXS.

Petree W (2018) A Participatory Action Research Project to Identify the Psychological Service Needs of Students with Disabilities in a Four-Year University, Ann Arbor: Our Lady of the Lake University.

Rayini J (2017) Library and information services to the visually impaired persons. Library Philosophy and Practice: 1-13. Retrieved from http://digitalcommons.unl.edu/libphil prac/1510.

Simons H (2009) Case study research in practice. London: Sage Publications Ltd.

Waale MF (2017) Supporting Differently-Abled Students in Two New Jersey Community Colleges. Rutgers The State University of New Jersey New Brunswick, Ann Arbor. Retrieved from https://bit.ly/35iDdGl. 



\title{
Intercultural Education: Bring Together Pluralism and Diversity
}

\author{
By Elvira Martini
}

\begin{abstract}
Large-scale migrations have forced the creation of new scenarios where the sense of absolute freedom clashes with the search for an ideal community. This situation poses problems related to identity, diversity, the 'discovery of the other' and, therefore, to identifying forms that allow to bring together more and more multi-cultural populations (Benahbib 2002). The aim of this paper is to reflect on the need to consider the educational process as 'methodical socialization' which corresponds to the need for any society to secure the bases of its conditions of existence and of its durability (Filloux 1993). For these reasons the education processes must be based on format with high coefficients of self-reflection, convergence, trans-culturalism. Education, as a social fact, must adapt to change and new alphabets, to overcome the binomial between time to learn / time to work and must insist on creativity and innovation, since everyday life is and it will be increasingly governed by knowledge and, particularly, by the spendable knowledge, a typical feature of complex, cosmopolitan and 'high knowledge claim' societies.
\end{abstract}

Keywords: coexistence, education, inter-culturalism, trans-culturalism, socialization

\section{Introduction}

In the current social context, meeting "the other (the different person from me)" is no longer an event limited to sporadic episodes, but it becomes something that falls within the normal everyday life situations.

However, the migration phenomenon (which in itself represents an opportunity for enrichment) is too often accompanied by media messages that promote fear and suspicion for all diversity, spreading ideas that stigmatize entire populations based on individual behaviour.

It follows that the relative social integration of immigrants is characterized by a significant distance between the latter and the native population. It is clear that this situation poses problems relating to identity, diversity, the discovery of the other and, therefore, to identify forms that allow for coexistence among more multicultural populations.

The shortening of this social distance can be achieved through the creation and experimentation of "spaces" within which to educate young people and adults to "contamination" between different realities, understood as a spirit of sharing, mutual acceptance, constructive exchange and enrichment of values.

\footnotetext{
"Associate Professor of Sociology, Università Telematica "Giustino Fortunato", Italy.
} 
In this process, in addition to the family, educational institutions play a fundamental role, as the first mediators of social inclusion that aims to avoid separation on ethnic, linguistic, religious and cultural bases. Inclusion, cultural and social exchange must be supported by an educational idea that aims at the "recognition not so much of fundamentally equal but rather of irreducibly different from" (Di Nicola 2015: 47).

Therefore the strong idea of an actor involved in social processes emerges; an actor who safeguards the principle of the centrality of the person, also in the educational-training process. The current socio-cultural context and its systemic complexity offers (to the construction of the personality) the possibility of opening up to otherness and exchange but also continuous solicitations for the subject to extend himself to participation and shared responsibility. In this process, the person is perceived as a tension towards the encounter with the other and towards an increasingly extended dialogue (Piu 2015: 8).

Inevitably, all this has an impact on the training systems that, to realize an effective didactics of the dialogue, must necessarily adapt their training proposal, building innovative and creative didactic paths that are transcultural. A didactics understood as mediation, dialogue, relationship, interactivity, reflexivity, able to contribute to the formation of cognitive autonomies ready for dialogue, cooperation, understanding the indispensability of the other.

\section{Recognize Oneself in a Complex and Transcultural Society}

The era in which we live can be defined as the era of differences and uncertainty: individual, territorial and cultural differences, which postulate the meeting between peoples and civilizations and for which the keywords become multicultural, intercultural, trans-cultural (Piu and Pitto 1993).

In other words, the phenomenon of complex society places political, sociological, and even pedagogical attention on the concept of social inclusion, not so much based on the principle of equality as on that of egalitarian difference (Benahbib 2002), a principle that postulates the 'participatory and meaningful inclusion within a community, actively contributing to its development and its economic and political growth. But even more to the concept of integration, understood as the need for recognition of the self and of the claim of one's cultural identity. And starting from the current socio-cultural scenario -which inevitably suffers the effects of globalization and cosmopolitanism as well as that which Giddens (1990) calls the second modernity- that the struggles for recognition live a renewed season, precisely because the emergence of particular political, social and cultural conditions have made the systems incapable of accepting and including within them the different units (Di Nicola 2015: 47).

In fact, despite the myth of globalization (Cesareo and Magatti 2000), which would tend inexorably towards the unification of the world, we find ourselves faced with a ubiquitous patchwork: global processes do not tend naturally towards unity or 'uniformity, but on the contrary, if left to themselves, they help to remove the ideal of the community, producing instead strong imbalances, inequalities, 
exclusions that select (and not only symbolically) who should be kept out and who can be included. We are witnessing an ambivalence between forms of exclusionary inclusion and softer forms, although not entirely definitive, of selective inclusion and therefore to "an ambivalence that creates differentiations and grades the levels of inclusion and marginalization" (Tucci 2018: 57) ${ }^{1}$.

However, in this situation it is justified that the demand for a liveable community among men and women becomes more and more pressing, although it seems that we should be satisfied only with community surrogates, as the communities no longer present themselves as a natural fact. And unlike natural communities, these surrogates fail to resolve the dichotomy of freedom/security, rather they sharpen it: "if it is true that the community gives security, it requires a certain sacrifice of freedom" (Bauman 2001: 6). Modern individualism makes us increasingly insecure, because it offers (and not to all) freedom in exchange for security. And the vulnerability of individual identities leads to the search for "crutch-communities, on which people hang their worries, otherwise experienced individually" (Bauman 2001: 17).

The need to rediscover a space-centric unity is accompanied by what Hobsbawm and Ranger (2002) call the invention of tradition, a possible response to rapid social change, a need to establish continuity with the past, through social and ritual practices that ensure socialization and social cohesion.

However, it is precisely the return to tradition that lends itself to an inevitable pitfall: continuing to consider the community as a place of homologation and identity and not rather as a place of contamination between local and global, between equal and different, of the conviviality of differences (Nanni and Weldemariam 1994). In this sense, then, the community would be invented to exorcise the fear and neutralize the danger, by joining together (Berti 2005: 68).

This "narrow and silent" vision of community highlights all its limitations when the fear of the other is read as fear towards the foreigner: "not being together but avoidance and being separated have become the main strategies for survive in contemporary megalopolises" (Bauman 1999: 55).

According to Bauman, even the new cosmopolitans feel the need for "community", only that, obviously, they tend to recreate flexible and "timed" communities, which can be easily dismantled and that only leverage on their dreams and desires. This means an unbridled search for a safe and overprotected social environment, and the community becomes the favourite tool of those who believe that "identity" only means exclusion of the other as different. Therefore the "safe community" becomes a "voluntary ghetto". All this increases the selfperpetuating mechanisms of segregation and exclusion.

It is very probable that 'identity-ism' (this great identity myth) is actually a defence strategy for our privileges. But it is a short-sighted strategy that fosters

\footnotetext{
${ }^{1}$ On the issue of inclusion, or rather expulsion, Saskia Sassen also expressed, whose sociological analysis was conducted in support of the thesis that the expulsions would represent the result of predatory formations that are expressed in "decisions and actions that have their own weight, but that are part of large assemblages of elements, conditions and dynamics that mutually reinforce each other" (2015: 88).
} 
conflict: people who use this strategy do not know how to see any other solution than their own privileges and advantages. Beyond the "we" there are only enemies (Remotti 2011, 2017).

The search for a safe space underlines the importance of the emotional dimension of globalization. The 'indicators of self-confidence', as Moïsi calls them (2009: 22) scientifically measure the level of trust of a population in their future, the ability to know how to use their skills and even transcend them. And the level of self-confidence is well expressed by three primary emotions: fear, hope and humiliation (Moïsi 2009: 22). The rediscovery of emotions is necessary where states, like those in the West, can no longer rely on historical ideals or economies that have become too evanescent; in these scenarios, therefore, an attitude of bitterness and a desire to protect oneself from hostile forces is born. "But the main reason why today's globalized world is a fertile ground for growing emotions is that globalization produces insecurity and raises the question of identity. [...] Identity is closely linked to self-assurance and in turn self-confidence, or its absence, is expressed in emotions, particularly in fear, hope and humiliation" (Moïsi 2009: 29). The myth of identity arises in a context of globalization, in which relations between countries and cultures have become increasingly dense and increasingly risky and conflicting. Remotti defines it as the "product of cultural impoverishment; [...]. Because of identity, we see only what threatens us in relationships with others, and this is a huge cultural poverty. In this context, the myth of identity also combines with fear: the fear of losing one's things, one's privileges, one's substances; the great fear of having to share. We therefore cling to identity as something that illusively gives us security: an illusory security, a fallacious and dangerous myth" (Remotti 2011, 2017). Although the key to understanding others is the intertwining of these emotions, emotions very often generate that emotional discomfort that can arouse situations of non-recognition of the face of the other and indifference.

This is what happens when those who cross the border become for us a "radically different", not attributable to our world and towards which it is very difficult to activate the ethical action of solicitude (Ricoeur 1997).

All this means that the construction of multiple identities (individual and social) is shown as a difficult and high-risk process, especially when the need for roots and rooting exacerbates the differences, heightening individualism and insecurity. That same insecurity that the individual suffers in the era of globalization and that generates the absence of community. "When the community collapses, the notion of identity is invented" (Young 1999: 164). And identity means getting out of the deck, it means being different and, as such, unique; and therefore the search for identity can only divide and separate. However, the vulnerability of individual identities leads to the search for "crutch-communities", on which people hang their concerns together, otherwise experienced individually (Bauman 2001: 17).

In this sense, acceptance assumes the meaning of interaction, relationship, inter-subjectivity. And as such it is the result of the ego-alter dialectic, of the meeting of two diversities that at the moment of mutual recognition do not get confused and do not merge but are constituted autonomously by difference 
(Bauman 2001: 49). Recognizing and accepting becomes all the more necessary the more the social becomes fragmented and multiplies in spheres of reality that encompass levels of knowledge of common sense and as such feed the processes of reflexivity in the construction of personal identities that can only be, therefore, multiple and plurals (Di Nicola 2002). Consequently, also culture, understood as an institutionalized form of knowledge, is fragmented and distributed in a multiplicity of 'divergent worlds' (Di Nicola 2002: 49), losing part of its performance capacity of individual behaviour and becoming a process of learning, reorganization of cognitive maps and re-orientation to action (Bauman 1999).

Therefore, the migratory universe brings to a new conception of culture that can be defined, precisely, as trans-culturality (Welsch 1999) and that contributes even more to strengthening the paradigm of the formation of multiple identity.

Multiculturalism (understood as the coexistence of different cultures) and its direct development, inter-culturality, have revealed their limitations over time, as they are rooted in a traditional conception of culture that maintains a marked insistence on 'difference', on the sense of "otherness" in the contact between cultures. And where emphasis is placed on the differences between groups, there is a risk of creating even more distance between them and one can even, without intending it, initiate segregation and ghettoization processes. Cultural barriers remain and one can incur reaffirmation and reinforcement of stereotypes. Moreover, the process of recognition and valorisation of otherness can lead to vain and often harmful essentialisms and to an exasperated idealization of the culture or country of origin (Tumino 2011: 603). Amselle (2007: 81) would say "the métissage would be perceived as an invasion syndrome, so any overcoming of barriers, any encroachment in the other territory would turn into a real concern for the creation of bastardise situations (bastardization)". Therefore, despite good intentions, inter-culturality could produce perverse effects and lead to cultural or even 'racist' fundamentalists.

It is clear that this concept is inadequate compared to the multiplicity of cultural inter-connections (increasingly dense and complex) typical of globalization and trans-nationalization. "In a multicultural context that involves meetings, conflicts and contaminations between people, peoples and cultures are multiplied and the closed conception of cultural systems is unattainable, today. In fact, they have always been fed by hybridizations and exchanges" (Tumino 2011: 604).

To explain the processes of formation of these new, modern and multiple cultural forms, new conceptualizations and models of cultural interaction are therefore necessary. The concept of trans-culturalism, precisely, responds exactly to this need.

Welsch, in this regard, puts the emphasis in cultural fertilization at multiple levels, from the macro-level of societies - whose cultural forms are characterized by internal differentiation, complexity and hybridization - to the micro-level of individual experience, where personal and cultural identity almost never corresponds to the civic and national one and it is instead increasingly marked by multiple cultural connections. From the pragmatic point of view, the traditional concept of cultures as discrete units (which, placing the emphasis on what is 
proper to a people and the exclusion of everything that is different and foreign, tends irremediably to a sort of cultural racism) is overcome by trans-culturality which aims, instead, at an intersected and inclusive vision of culture: It intends a culture and society whose pragmatic feats exist not only in delimitation, but in the ability to link and undergo transition (Welsch 1999: 200). Therefore, transculturality must be understood not only as a model of analysis of modern reality, but also as an ideal to which to tend in the daily practice of cultural interaction: It is a matter of readjusting our inner compass: away from the concentration on the polarity of the own and the foreign to an attentiveness for what might be common and connective wherever we encounter things foreign (Welsch 1999: 200).

Where trans-culturality becomes the analytical model for reading today's cultural reality, trans-culturalism could be a more suitable term to designate a will to interact -starting from intersections rather than differences and polarities-, the awareness that in all people there is a trans-cultural dimension, which helps us to better understand and welcome what is outside of us, a vision that favours flexibility, movement and continuous exchange, the continuous renegotiation of identity (Tumino 2011: 607-608).

\section{Behind the Borders: Safer or More Isolated?}

The matter of the border stands as the matter of the space to occupy (Martini and Vespasiano 2016: 82-84).

"The important thing in order to claim any right within an unlimited space is to enter it, to settle there, to sneak inside, taking possession of an area of interest, to occupy an area that, each time, may be social, political, sexual, mental and economic. Only after occupying this space, if you want, you can trace the outline, close it within a boundary and delimit it. The experience of the border starts, therefore, always from the inside" (Zanini 1997: 30-31). Therefore, "it is hard to think that someone belongs to something (to a community, a political organization) without imagining, at the same time, a policy of separation, the definition of boundaries (Costa 1999: 43). It is, therefore, the function that the border plays in defining an "inside" and "outside", with respect to the reference community, to give it the character of "establishment of institutions" (Balibar 2010: 315).

According to an interesting perspective on the origin of the concept of border it can be understood as: limen or limes (Cacciari 2000: 73-79). Limen is the threshold, the pass through which one enters a domain or comes out of it and limes is, instead, the path that surrounds a territory, which contains its form.

Based on this etymological suggestion, Gomarasca supposes a boundary model organized according to two fundamental theses. "The first thesis (T1) concerns the structure of the border, its essential duality: there is no boundary that is not limen and limes together. In fact, the border is never rigid. It indicates the line along which the two men are touching (cum-finis) ${ }^{2}$. The second argument

\footnotetext{
${ }^{2}$ Simmel's picture of the frame metaphorically describes very well this thesis: "for the social group,
} 
(T2) concerns the writing of the border: we can live (and therefore build) a space only if we draw boundaries. Here, above all, the anthropological significance of the concept is at stake: each of us constantly establishes borders while acting and interpreting the world (Mezzadra 2000: 149). In other words, men are beings who produce, wherever they live, guarded spaces" (Gomarasca 2004: 18).

The correlation of these two theses leads us to affirm that the boundary makes distinctions while uniting and therefore "no border can eliminate or leave out another one, because it implies it in its very being" (Gomarasca 2004: 19). However, only rarely it happens that solidarity mechanisms activate processes of concern to the other; in most cases it is the opposite to occur, with episodes of hostility, fear and indifference, evoking ethnocentrism as a universal feature of human groups. "A natural consequence related to the construction of the border is to throw out from the area that has been created s/he-what is considered as an intruder. Exclusion leads someone or something to the edge of an area, away from the centre: this is where the outcast is (Geremek 2012: 391-421). And sometimes this can also be pushed over the border until it becomes a foreigner, that is something other than what you want to contain within the boundary" (Zanini 1997: 55).

This attitude towards the other has a strong correlation with the social structure and cultural environment. "The attitude towards the foreigner depends on the way of feeling and being of the community, social groups and individuals. The individual and, above all, the community identity, determines the attitudes and strategies of action" (Cotesta 2002: 5). In other words, the exclusion mechanism arises from the inability to be able to classify, by their own cultural categories, the peripheral elements, seen as deviant, dangerous anyway. This is how "the stranger becomes someone who is not a member of our own field from the beginning; then when s/he gets there, s/he imports a set of special features, qualities, which, in the long run, can modify, more or less in depth, its character" (Zanini 1997: 60).

The stranger disrupts the familiarity of the space of belonging and requires, in any case, to rearrange this space and to revise the limits ${ }^{3}$. This reorganization depends on the ability to integrate other individuals in own environment; when there is no such ability, we add a little self- confidence, then we tend to assume basically suspicious and hostile attitudes" (Simmel 1989: 580).

In short, "on the border and across the border differences are structured: the symbolic, the legal and the political ones. Differences having other differences, between those who have rights and those without; between those who belong to a particular community and those who are excluded" (Nuzzo 2006: 129). Thus, the boundary builds its own citizens according to approval and uniformity criteria

the frame assumes a function very similar to that which it has for a work of art. In this one it exerts the two functions, which are exactly the two aspects of a single function: to mark the boundary of the work of art as to the surrounding environment and to close it in itself' (Simmel 1989: 529).

${ }^{3}$ Being a foreigner, for Simmel, means that "the distant subject is near" (1989: 582) and that the difference is close to our environments and insists to enter and remain there; the stranger is not exactly "the traveller who today comes and tomorrow goes, but [...] the one who today comes, and tomorrow stays - so to say the potential traveller who, not having continued to move, has not entirely overcome the absence of ties of going and coming" (Simmel 1989: 580). 
(inward), becoming a "necessary condition and, at the same time, 'non-democratic' of democracy" (Rigo 2015: 10-14).

\section{Educational Process as 'Methodical Socialization'}

The purpose of this work is to reflect on what attitudes to assume, moving from the culture of individualism (typical of the dominant culture) to the culture of partnership, which is based on dialogue and cooperation. The cultural model of individualism characterizes the educational systems of many countries where the problems related to globalization and awareness of current realities are not considered relevant to national programs, while the partnership model favours international cooperation between nations and peoples (North-South Centre of the Council of Europe 2012: 13).

Therefore, we need to identify ways that allow the coexistence of more and more culturally heterogeneous populations, indicating methods and rules that govern this cohabitation within the same social configuration.

In this situational framework, we ask ourselves about the need for a new educational model with a high coefficient of convergence and unity, as well as on the elaboration and experimentation of real integrated curricula, that respond to the needs of transcultural communication. Delors (1996), clarifying the objectives of education, recognizes that one of the fundamentals of knowledge is undoubtedly the ability to know how to build meaningful relationships with others, so as to identify in the expression 'learning to live together' one of the highest goals of every training system.

This is because considerable importance is given to the ability of each subject to be able to cooperate and collaborate constructively with others without distinction of sex, religion, ethnicity, culture or values (Piu 2015: 7).

Transformative learning generates a profound and structural change in the premises of thought, feelings and actions, through intercultural education. This education of mind and heart is followed by a radical change that goes towards interconnection and the adoption of all the instruments to guarantee greater equity, social justice, understanding and cooperation between peoples.

Intercultural education as transformative learning leads to participatory decision processes at all levels. The objective of this type of learning consists in strengthening mutual knowledge and the collective awareness of oneself (NorthSouth Centre of the Council of Europe 2012: 14).

With the shift of attention to the transformation from a culture of reproduction and domination to a partnership based on dialogue and cooperation, intercultural education modifies the rules established by the global economy, bringing human dignity back to a central value.

In an interesting article (1911), entitled 'Education, its Nature and Role' published in Education et sociologie, Durkheim asserts, on the basis of 'historical observation', that "every society, considered at a given moment in its development, has a system of education which is imposed on individuals". Every society sets itself a certain 'human ideal', an ideal of what a person should be from the 
intellectual, physical and moral points of view; this ideal is the crux of education. Society can subsist "only if there is sufficient homogeneity among its members". Through education, the 'individual being' is turned into a 'social being'. [...] "It emerges from the foregoing definition that education consists of a methodical socialization of the young generation" (Durkheim 1992: 51).

This view of education as 'methodical socialization' corresponds to the need for any society to secure the bases of its 'conditions of existence' and of its durability (Filloux 1993: 3).

The definition proposed above, however, merely describes the 'fact' or essential nature of education at a given moment, from a static point of view. However, not only do societies 'change', evolve and have a history, but within those societies themselves, the institutionalized education systems that are consistent with their needs also evolve and, in turn, generate their own needs. The 'science of education' as the objective study of the social fact of 'education' must consequently situate these systems in the context of a general dynamic which can in fact be described by analysing it in terms of stages in social reality (Filloux 1993: 3$)^{4}$.

For these reasons, otherness acquires a meaning and a value that must necessarily overcome the simple tolerance of the different or its cultural assimilation; therefore, it becomes very difficult to set up a cross-cultural policy, since each of us has a tendency to conform to the conventions and convictions of the ethnic group of belonging, without worrying about the partiality or the limitation of one's own point of view.

A cultural revolution that brings the different, the foreigner that makes him/ her know and "feel" close must be postulated, as indispensable and necessary. A cultural revolution that rationalizes atavistic fears, unconscious aggressiveness and difficulties through dialogue, rapprochement and cohabitation (Cambi 1993).

So, education (this process of methodical socialization) is the preferential path to socio-cultural integration. This is true when it focuses on three central aspects: the quality of the training provided, the 'global needs' of immigrants and the projects of migrants and their families (Fiorucci 2007). "Training, for the immigrant, is a summary of reception and stabilization. The immigrant agrees to undertake an educational path both to coexist in the ambiguity of his condition and to get out of it. He begins a process of linguistic, socio-cultural and professional re-identification because he knows that he can no longer bear to live only with the 'gift-refuge' represented by his own language, mentality, and operativeness. The immigrant seeks the security that the contents of the training can give him (from the first literacy to professional training)" (Demetrio and Favaro 1992: 33).

\footnotetext{
${ }^{4}$ Let us consider the main thrust of the durkheimian model. Central to it is the concept of conscience collective. A society is composed of individuals who 'cohere' because they share common values and rules, partly transmitted by school. Society, as an object constructed by sociology, has its own specific nature defined by the parameters of 'integration' (allegiance to the group) and 'regulation' (recognition of rules controlling individual behavior). This conscience collective is reflected in collective phenomena ranging from the strictly mental level of collective representations to the level of 'institutions' and that of a 'material substrate' (volume and density of population, communications, buildings, etc.) (Filloux 1993: 4).
} 
Training alone cannot solve all the problems of integration of migrants: the outcome of the integration paths also depends on the more complex integration policies that a country is willing to implement. Integration policies that, without neglecting the primary needs, must overcome the emergency approach that tended to consider immigration not as a structural phenomenon but as a contingent phenomenon (Fiorucci 2007).

If this happens, training can become a preferential way to integrate immigrants into the economic, social and cultural context of the host countries: "we must learn to recognize in each stranger a person who brings with him a history and a memory, which has a culture and a homeland, a life project, skills to enhance and things to say; that he meets different and differently acute problems according to the ethnic group, from his being a man or a woman, young or old; which has not only needs for food or lodging, but also for communication, sociability, affection and culture. It is about looking at the facts with a new representation and, therefore, doing a cognitive renovation. This is indispensable if we want to send to foreigners the new and different image we must have of them" (Susi 1991: 20).

\section{Conclusions}

The different ways of delivering knowledge (presence, at a distance, blended learning) must adapt to the changing needs of the knowledge and skills society and be linked to a concept of culture that makes pluralism and difference live together.

To do this, three fundamental acquisitions are necessary, in order to ensure adequate intercultural and transcultural training processes:

1. to leave the 'myth of the emergency' to assume cultural diversity as the school paradigm, which requires a 'continuous and structural' intercultural planning (and not a 'temporary and special' project);

2. the presence of foreign students represents "a precious opportunity to rethink their educational, didactic, relational and organizational models and to challenge them";

3. intercultural education ${ }^{5}$ is one of the elements of the anthropological renewal process ${ }^{6}$ of the theory and practice of education that is "necessary

\footnotetext{
${ }^{5}$ Intercultural education is a generic expression that refers to the pedagogical concepts related to the realities of today's world. It is therefore an open, evolving and multidimensional concept of contemporary general education. Furthermore, it is considered a holistic collective response to the historical challenge, consisting in helping active global citizens, to create and recreate a different world, more equitable, fairer, more peaceful, more sustainable, based on international solidarity (North-South Centre of the Council of Europe 2012: 20).

${ }^{6}$ On several sides, we insist on the importance of teaching anthropology in schools of all levels. It is of fundamental importance to get the discipline out of its specialized horizons and make it a knowledge for everyone: a discipline capable of dialoguing not only with other disciplines, but also with all those professional figures who play some educational and training role. Anthropology is also a way to preserve the exercise of critical autonomy and to guarantee democratic but also critical and conscious action, both inside and outside the classroom. Children must live in an environment
} 
for everyone, for the new generations, for whom a good multilingualism education affects the future of all young people, where curiosity and openness to different cultural forms are not welcome gestures but important skills to face the world of work" (Pastori 2010: 191-192).

Intercultural education allows individuals to develop their knowledge and skills, to adopt values and aptitudes suitable for building a just and sustainable world in which all individuals have the right to exploit their potential.

Figure 1. The Dimensions of the Intercultural Education Process
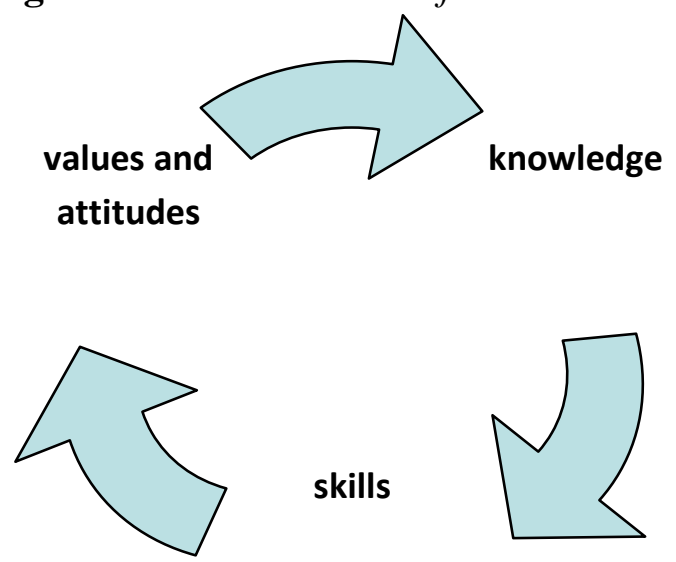

Source: Our calculation by North-South Centre of the Council of Europe 2012: 20

Consequently, in the learning process of intercultural education, students and educators deepen their reflections on the roots and causes of events and developments and share ideas on possible solutions, within the framework of a dynamic exercise of observation, analysis, reflection and exchange of information that generates a new field of knowledge and interests. Differences in sex and social class, as well as ethnic, religious, socio-economic and cultural differences faced during the dialogues, will be part of the questions and problems discussed and possible solutions adopted. Within the framework of this process, knowing refers to everyday knowledge, to the vision of life and all its aspects through a local and global prism, to an interconnected and interdependent approach, aimed at reenergizing the learning process and making the external world become an integral part of the analysis of daily life (North-South Centre of the Council of Europe 2012: 21).

This means that in education and training processes there are essentially three tasks, particularly complex and delicate:

1. the enhancement of differences to allow going beyond cooperative relationships and recreating symbolic channels capable of conveying

that educates them to pluralism, where they are taught that there is a different thought than the dominant one, imposed by society or by the adult. 
universally shared values;

2. the creation of a profound intercultural ideal tension to achieve effective goals of democracy and new forms of solidarity and non-homogeneous coexistence;

3. the promotion of a proper capacity to succeed in resolving conflicts, in order to generate relationships capable of characterizing the context of relationships as a generative peace environment (Piu 2015: 9).

So the key words become difference cohabitation, relationality, connection and they are understood as universally shared values and as current and poietic educational instants, the only ones able to ensure the transition from an ethnocentric orientation (negation, defence, minimization) to an ethno-relative one (acceptance, adaptation, integration) (Hammer et al. 2003).

Therefore, education as a social fact must adapt to change, to new alphabets, to overcome the binomial time to learn / time to work and must insist on creativity and innovation, since everyday life is and it will be increasingly governed by knowledge and, particularly, by expendable knowing, a typical feature of complex, cosmopolitan and 'high knowledge claim' societies.

\section{References}

Amselle J-L (2001) Connessioni. Antropologia dell'universalità delle culture. Torino: Bollati Boringhieri,

Amselle J-L (2007) Dal métissage alla connessione. In La società di tutti, F Pompeo, (ed). Multiculturalismo e politiche dell'identità. Roma: Meltemi.

Balibar É (2010) At the borders of citizenship: A Democracy in Translation?. European Journal of Social Theory 13(3): 315-322.

Bauman Z (1999) La società dell'incertezza. Bologna: il Mulino.

Bauman Z (2001) Voglia di comunità. Roma-Bari: Editori Laterza.

Benahbib S (2002) The Claims of Culture. Equality and Diversity in the Global Era. Princeton University Press. Princeton.

Berti F (2005) Per una sociologia della comunità. Milano: FrancoAngeli.

Cacciari M (2000) Nomi di luogo: confine. In "Aut aut," vol. 299-300, 73-79.

Cambi F (1993) Il dialogo tra uomini. In Multiculturalità e integrazione delle etnie, C Piu, C Pitto, (eds). Nuovo Albero e Elica. monografico, 3-4.

Cesareo V, Magatti M (eds) (2000) Le dimensioni della globalizzazione. Milano: Franco Angeli.

Costa P (1999) Civitas. Storia della cittadinanza in Europa, vol. 1: Dalla civiltà comunale al Settecento. Roma-Bari: Laterza.

Cotesta V (2002) Lo straniero. Pluralismo culturale e immagini dell'Altro nella società globale. Roma-Bari: Laterza.

Delors J (1996) Nell'educazione un tesoro. Roma: Armando.

Demetrio D, Favaro G (1992) Immigrazione e pedagogia interculturale. Bambini, adulti, comunità nel percorso di integrazione. Firenze: La Nuova Italia.

Di Nicola P (2002) Amichevolmente parlando. La costruzione di relazioni sociali in una società di legami deboli. Milano: Franco Angeli.

Di Nicola P (2015) Riconoscimento e rispetto: la dialettica ego-alter nella società della diversità. In Sociologia Italiana, 6: 43-60.

Durkheim E (1992) Education et sociologie. Paris: Press Universitaires de France. (ed. or 
1911).

Filloux J-C (1993) Emile Durkheim (1858-1917). In Prospect: the quarterly review of comparative education. 23(1/2): 303-320.

Fiorucci M (2007) Formazione e immigrazione, LLL (Focus on Lifelong Lifewide Learning. Anno 2, n. 8. Retrieved from https://bit.ly/3aQmLQL.

Geremek B (2012) L'emarginato. In L'uomo medioevale, J Le Goff (ed), 391-421. Laterza. Roma-Bari.

Giddens A (1990) The Consequences of Modernity. Cambridge: Polity Press.

Gomarasca P (2004) I confini dell'altro. Etica dello spazio multiculturale. Milano: Vita e pensiero.

Hammer MR, Bennet MJ, Wiseman R (2003) Measuring intercultural sensitivity: The intercultural development inventory. International Journal of Intercultural Relations 27(4): 421-443.

Hobsbawm EJ, Ranger TO (2002) L'invenzione della tradizione. Torino: Einaudi.

Martini E, Vespasiano F (2016) To re-educate oneself to citizenship within the cultural pluralism. Journal of Mediterranean Knowledge-JMK 1(1): 79-90.

Mezzadra S (2000) Cittadini della frontiera e confini della cittadinanza. Per una lettura politica delle migrazioni contemporanee. In "Aut aut" vol. 298, 133-153.

Moïsi D (2009) Geopolitica delle emozioni. Le culture della paura, dell'umiliazione e della speranza stanno cambiando il mondo. Milano: Garzanti Libri.

Nanni A, Weldemariam H (1994) Stranieri come noi. Dal pregiudizio all'interculturalità. Bologna: EMI.

North-South Centre of the Council of Europe (2012) Global Education Guidelines. Lisbona.

Nuzzo L (2006) Cittadinanza: Un percorso di lettura. In Rechtsgeschichte 8: 129-147.

Pastori G (2010) Nello sguardo dell'altro. Pedagogia interculturale e identità. Milano: Guerini.

Piu C (2015) Complex society and education [Società complesse e formazione]. In $Q$ Times Webmagazine. VII(2). Retrieved from http://www.qtimes.it.

Piu C, Pitto C (eds) (1993) Multiculturalità e integrazione delle etnie. Nuovo Albero a Elica, monografico.

Remotti F (2011) L'ossessione identitaria. In Rivista Italiana di Gruppoanalisi. XXV, 1, 9-29. Retrieved from https://bit.ly/2RVneID.

Remotti F (2017) L'ossessione identitaria. Roma-Bari: Laterza.

Ricoeur P (1997) La persona. Brescia: Morcelliana.

Rigo E (2015) Confini e cittadinanze. In Rivista di Storia delle Idee 4(2): 10-14.

Simmel G (1989) Sociologia. Milano: Edizioni di Comunità.

Sassen S (2015) Espulsioni. Brutalità e complessità nell'economia globale. Bologna: il Mulino..

Susi F (1991) I bisogni formativi e culturali degli immigrati stranieri, La ricerca-azione come metodologia educativa. Milano: Franco Angeli.

Tucci A (2018) Dispositivi della normatività. Torino: Giappichelli Editore.

Tumino R (2011) Transculturalità e trans-culturaliismo: una nuova (?) frontiera della ricerca pedagogica. Aracne. Roma. Retrieved from https://bit.ly/3aKMBWl.

Welsch W (1999) Trans-culturality: The puzzling form of cultures today. In Spaces of Culture: City, Nation, World, M Featherstone, S Lash (ed), 194-213.

Young J (1999) The Exclusive Society. Crime and Difference in Late Modernity. London/Thousand Oaks: Sage Publications.

Zanini P (1997) Significati del confine. I limiti naturali, storici, mentali. Milano: Bruno Mondadori. 



\title{
First Correlation Study between Family Organizational/ Administrative Functionality Scale Results and School Performance of the Young Human Capital at Public and Private Elementary, Middle and High School of the South/ Center of the US, Territory of Puerto Rico
}

\author{
By Sandra Vélez-Candelario
}

\begin{abstract}
This quantitative study presents the first correlation between Family Organizational and Administrative Functionality and School Performance. To evaluate Family Organizational and Administrative Functionality is using the FOAF Scale (VélezCandelario, S., 2019) and the overall percent of it. This scale has 90\% of the overall value. The intern consistency and the Factor Analysis are, .89 (Cronbach's Alpha) and the Factor Analysis shows a .8 KMO (Kaiser-Mayer-Olkin), recognizing each measured area as an independent factor. To analyze the school performance, we are using the General Point Average (GPA) at the school of each one of the participant. The study includes a socio-demographic document and parent consent. The sample is twohundred-sixty-five (265) children with six (6) to seventeen (18) years old from public and private schools. It was from the south and center zone of Puerto Rico, with an education system based on the American model (Classbase, 2018). The sample is selected by availability from volunteer families and from Puerto Rico's Department of Educationn. The hypothesis investigation $(\mathrm{Hi})$ is: Exist a positive correlation between Family Organizational/Administrative Functionality and school performance. For the statistical analysis, the sample is submitted in the SPSS 26 version and applies a Pearson's correlation formula and a sample descriptive Statistics. The findings show a positive correlation with a significance level of 0.01. The Pearson correlation degree between, FOAF and GPA, is medium, $\rho=.341^{* *}$, (Cohen 1988; in Wuensh 2015). The small correlation effect size is one in which there is a real effect, but one which can only be see-through careful study. A large effect size is an effect which is big enough such that it may be visible to the naked eye (Cohen 1988 in Walker 2007-08). The statistics analysis allowed the acceptance of the Hi confirming the existence of a positive correlation between FOAF Scale results and GPA at School.
\end{abstract}

Keywords: Family, Organizational, Administrative, Functionality, Scale, School, Performance, Correlation.

\section{Introduction}

In some ways, the home management has never been more challenging. The cost of living and the standard of comfort are going up by leaps and bounds. It is essential today to know something about food values and arrangement of meals that avoid monotony and provides the required variety in nourishment on which the excellent health (and, ultimately, the good temper of the household) depend (Ravenhill and Schiff 1911). How can family leaders fulfill these duties as needed if they are utterly ignorant of the laws of health and child-life? How are they affected by their surrounding environment and all of the other grave and

${ }^{*}$ CEO, Young Human Capital Research, Corp./Family Organizational Science, USA. 
fundamental truths which lie at the root of the successful upbringing and development of the child? Scientific training in Household Administration can alone save the sorely taxed housewife of today from becoming more than a slave to her domestic responsibilities (Ravenhill and Schiff 1911). Progressive social, commercial, industrial, and, last but not least, educational changes now require that this trained intelligence being foster by organized instruction. Such instruction, whether in the fundamental sciences or the applied arts, must be associated with individual practice in laboratory, studio, workroom, and kitchen; the details to be varied as circumstances dictate (Ravenhill and Schiff 1911).

Organizational procedures require intelligent activity, which in turn demands self-control. The human being requires emotional intelligence to acquire selfcontrol. Creative activity during a human being's household organizational and administrative process cannot take place without emotional intelligence. The family organizational and administration style determines how all family members deal with this, and with the consequences of it. This study recognizes the scientific intra-familiar organizational and administrative areas openly. It measures four specific areas that are analyzing in any other form of organization created by human beings like businesses, schools, churches, between others. These four areas are organizational culture, communication, leadership, and the environment. This study recognizes those as part of the management protocol of the intra-familiar setting (Vélez et al. 2016). The study used a mathematics tool named Family Organizational/ Administrative Functionality Scale (Vélez-Candelario 2019) to measure the performance of these four areas inside the household setting using the percent formula, from $0 \%$ to $100 \%$. The overall percentage of the FOAF Scale is correlated with the school's General Point Average (GPA) percent of the each one of the participants at elementary and middle school grades of the South/Center of the US, the territory of Puerto Rico. For the correlation analysis of Family Organizational/Administrative Functionality and the productivity at school, the study used the Statistical Package of Social Science (SPSS 26 version) computer program to introduce the collected data of the General FOAF Percent and the General Point Average at school of each one of the participants to apply a correlation formula.

\section{The Study Area}

This study analyzes the performance and quality of the organizational management and the administrative style in the intra-familiar setting that has young human capital active at school and how this affect their school performance. For the data collection, the study is using the Family Organizational and Administrative Scale (Velez-Candelario 2019) that measures the quality of the four essential organizational areas: Leadership, Communication, Organizational Culture, and Environment. This scale used the percent as the formula to see the quality of each area individually and the commute of each one as a whole performance. The study makes a correlation analysis to see if their intra-familiar 
organizational and administrative performance are influencing in their youngest and active human resources productivity at elementary and middle school grades.

\section{Previous School Performance Studies}

The school performance as a socioeconomic basic need promotes that many scientists try to analyze it as a very relevant topic. According with Trueman (2015), Pierre Bourdieu developed the cultural deprivation theory. This theory implies that higher class cultures are better when compared to working class cultures. Because of this perceived superiority, people from upper and middle classes believe people who are working class are themselves to blame for the failure of their children in education. He argues that working class failure in schools if measured by exam success is the fault of the education system, not working class culture. Cultural reproduction - the major role of the education system, according to Bourdieu, is cultural reproduction. This is the reproduction of the culture of the dominant classes. These groups have the power to impose meanings and to impose them as legitimate. They are able to define their own culture as worthy of being sought and possessed and to establish it as the basis for knowledge in the education system. However, there is no way of showing that they are any better or worse than other subcultures in society.

Other sociologists named Annette Lareau is the author of Home Advantage: Social Class and Parental Intervention in Elementary Education (2000), and coeditor of Social Class: How does it Work? (2009) and Education Research on Trial: Policy Reform and the Call for Scientific Rigor and Journeys (2009). Lareau's work is well known among sociologists, but neglected by the popular media in books like Unequal Childhoods. The sociologists Lareau has been able to capture the texture of inequality in America. She's described how radically childrearing techniques in upper-middle-class homes differ from those in working-class and poor homes, and what this means for the prospects of the kids inside (New York Times 2006-03-09).

Moreover, the journalist Rafal (2010) exposed that the book Home Advantage: Social Class and Parental Intervention in Elementary Education was originally written in 1989 and exposed Lareu's findings. Between those findings he mentioned:

1. Middle class parents do not set out simply to display their cultural resources. They are trying to pass these resources on to their children. They know that children will not automatically attain the same social status as their parents unless they do well in school.

2. Working class parents also believe that their children won't necessarily attain the same social status as themselves, and recognize that doing well in school will help children succeed in later life as well.

3. Working class parents have fewer resources to bring to bear to understand their children's school experience and less confidence to shape it. They see the teachers as professionals and trust them to have the children's best interests in mind. They use extrinsic markers like grades, stickers and 
comments on papers to track how their kids are doing in school. Since teachers almost always try to be positive the parents do not always recognize when a child is falling behind. Middle class parents are more interested in what their child knows and understands than necessarily in the grade mark.

4. Middle class parents differ in the conditions under and the extent to which they activate their cultural resources to shape their children's school experience. Being equally or more educated than teachers they evaluate teachers' performance. They may obtain supplemental experiences (tutoring, lessons, etc.) if they feel their child isn't getting all they need at school and/or they may be more likely to make requests of the school (for special programs, specific teachers, etc...). Middle class parents were most likely to activate their resources for a low-achieving child.

5. Only certain kinds of family involvement are desired by schools. Mainly: nurturing the child at home and sending them to school fed and groomed; reading to them; reviewing papers and homework; reinforcing behavior standards; and respecting the teacher. Families differ in their ability to do these things. Also middle class parents were more likely than working class families to not back up the teacher's discipline and to criticize the school or teacher for their educational program. Working class parents' criticisms were typically not about the academic program. But getting deeply involved in a child's inner life and school career can cause stress for the child and even exacerbate sibling rivalry or even marital tensions for some middle class families.

6. Teachers tried to be fair, but it seems that their expectations and even perceptions of children were colored by the involvement of their parents.

7. Lareau suggests that parent involvement "pays off" more in a school where it is rarer. In a school where most of the parents are busily involved, the parents end up competing for what then become scarce resources.

8. Lareau also looks at the parents' networks, suggesting that the middle class parents were more likely to form relationships with one another whereas working class parents socialized more with their kin groups. Whether among their friends or relatives, middle class parents were more likely to know (or be) change agents like principals, teachers, media, lawyers, judges, between others and thus informally learned how to meet criteria. She suggests teachers might invite an involved working class parent to bring a relative or friend with her the next time she volunteers as an example of how to leverage existing networks into a sort of mentoring system to expand parental involvement among the working class.

9. While this research added to knowledge of an intra-institutional relationship (home to school), it would be interesting in the context to see how a mix of middle and working class families in one school can work well.

Furthermore Weininger and Lareau (2018), expressed that decades after the publication of Pierre Bourdieu's key works, sociology of education remains the 
object of persistent misunderstanding. A coherent account of this work must distinguish, at minimum, two phases to Bourdieu's thoughts on education. According with these researchers, during the early period, Bourdieu asserted the salience of both self-selection and institutional selection in shunting students into class destinations that echoed their class origins. In contrast, Bourdieu's later work sought to develop a model of the relation between education and social inequality that had significant cross-national scope. This work de-emphasized the role of selfselection, and developed a substantially more nuanced account of the relation between education and social mobility.

On the other hands, Tena-Sanchez (2016), explained that the methodological individualism and social mechanisms first of all, one of Raymond Boudon's most important contributions to social sciences was his defense of methodological individualism and of causal explanations based on social mechanisms (also called causal or generative mechanisms). That is to say, the principle according to which any macro-social phenomena must be explained as a result of individuals' behaviour, which in turn is the result of these individuals' reasons and motivations. Also in turn, these reasons and motivations can only be understood in refers this is an old idea; Raymond Boudon made a decisive contribution to making this principle the basis of what constitutes an appropriate explanatory strategy in social science. This same researcher explained that Boudon developed this strategy in opposition to pseudo-explanations, either functionalist or structuralist ones as well as exclusively statistical ones, whose paradigmatic example was positivism. He was always a promoter of empirical sociology and a staunch defender of using statistical tools and formal models. However, he was also critical to the same extent of what has been called variable sociology (Esser 1996 as cited in TenaSanchez (2016), that is to say, the approach by which a phenomenon is explained when we identify a set of independent variables that predict the variance of dependent variables.

Otherwise, Tena-Sanchez (2016) explained scientific nature of social sciences and the study of educational inequalities for Raymond Boudon; the purpose of sociology should not be to move the reader or to make him/her enjoy, nor to transform society through political activism or even to produce data and analyses aimed at making decisions. Boudon was successful in showing how actions and interactions at the micro-level can produce aggregated outcomes at the macrolevel that nobody expects or wishes (perverse effects) without resorting to obscure teleological arguments or employing mere descriptive labels such as "socialization" with explanatory aims.

Is clear that previous scientists try to found scientific reasons or facts that affect the results of the school performance of the young human capital and cannot denied the family role on it, even more this group socioeconomic characteristics. These previous scientific observation also helps to understand the relevance of the family socioeconomic development. Any family organization, according with all these sociologists will have a better at school performance of their young human capital if they also have a better economic circumstance. A better socioeconomic development at home is not possible without a good organizational and administrative functionality (Velez-Candelario 2018). 


\section{Organizational Behavior and Organizational Theory}

The actions of people at work are called organizational behavior (OB) (Robbins and Coulter 2012). The Organizational Behavior (OB) is focusing on three major areas; individual behavior, group behavior, and organizational aspects. Individual behavior includes topics as attitudes, personality, perception, learning, and motivation. The organizational behavior is concerned with group behavior, which includes: norms, roles, team building, leadership, and conflict. The organizational aspects include structure, culture, and human resources policies and practices. This type of behavior is the focus of the study of psychology as a science (Robbins and Coulter 2012). According to Dictionary.com (2019), organizational psychology is the study of the structure of an organization and of how the people in it interact, usually undertaken in order to improve the organization. Moreover, Hellriegel and Slocum (2009) defined the organizational behavior as the study of the individuals and their groups inside an organizational context and the study of the process and internal practices that influence in the individual's affectivity, their team works, and the organizations. The Collins Dictionary (2019) defines it as the study of the structure of an organization and of how the people in it interact, usually undertaken in order to improve the organization.

Organizational psychology has basics organizational theories to analyze and explain organizational behavior. According to Jeffrey Pfeiffer summarized in New Directions for Organization Theory, organizational theory studies provide an interdisciplinary focus in different areas. Within them, the effects of individual characteristics and action on organization, the performance, success, and survival of organizations, the mutual effects of environments, including resource and task, political, and cultural environments on organizations and vice-versa, and concerns with both the epistemology and methodology that undergird research on each of these topics (Inc. 5000 2019). Another definition exposed that Organizational theory draws from various bodies of knowledge and disciplines. Some types of organizational theories include classical, neoclassical, contingency, systems and organizational structure. The classical perspective of management originated during the Industrial Revolution. It focuses primarily on efficiency and productivity and does not take into account the behavioral attributes of employees; it combines aspects of scientific management, bureaucratic theory, and organizational theory (Bach Pham 2018).

The Neoclassical Organizational Theory is a reaction to the authoritarian structure of the classical theory. It emphasizes the human needs of employees to be happy in the workplace. This theory also allows creativity, individual growth, and motivation, which increases productivity and profits. Managers utilizing the neoclassical approach manipulate the work environment to produce positive results. The Contingency Theory accepts that there is no universally ideal leadership style because each organization faces unique circumstances internally and externally. In Contingency Theory, productivity is a function of a manager's ability to adapt to environmental changes. This theory allows managers the freedom to make decisions based on current situations. The Systems Theorists 
believe all organizational components are interrelated. Changes in one component may affect all other components. Systems theory views organizations as open systems in a state of dynamic equilibrium, which are continually changing and adapting to environment and circumstance. Nonlinear relationships between organizational components create a sophisticated understanding of organizations (Bach Pham 2018).

\section{The Administration Theories and Management}

Administration or management is a daily human activity (Velez-Candelario 2018). The General Administration Theory is the rational conduct of the activities of an organization, with or without profit. It involves planning, organization (structure), the direction and control of all activities differences by the division of labor, running on an organization. Administration Theory is the field of human knowledge that works with the general study of administration, regardless of whether this applies to organizations for-profit or not. The TGA (for its acronym in English), studying the administration of organizations (Chiavenato 2000). The Merriam Webster dictionary (2019a) defined administration as the act or process of administering something; to manage or supervise the execution. Administrative management is concerned with the design and management of an organization. The Administrative management theory attempts to find a rational way to design an organization as a whole. The theory generally calls for a formalized administrative structure, a clear division of labor, and delegation of power and authority to administrators relevant to their areas of responsibilities (Grimsley 2019). According to Grimsley (2019) some of the pioneers of the Scientific Management are:

- Henri Fayol (1841-1925): Fayol was born in France, where he worked for a coal-mining business. He developed 14 administrative principles for organizational structure and management.

- James D. Mooney (1884-1957): Mooney studied mechanical engineering and eventually became a key member of General Motors' top management team. In 1931, he wrote Onward Industry! The book is considered by many scholars to be a significant contribution to organizational management theory.

- Luther H. Gulick (1892-1993): Gulick is often considered the 'Dean of Public Administration.' He applied administrative management theory principles to government.

On the other hands according to Meriam-Webster Dictionary (2019b), management is the act or art of managing: the conduction or supervision of something. To Business Dictionary (2019a), management is the organization and coordination of the activities of a business in order to achieve defined objectives. Management involves coordinating and overseeing the work activities of others so that their activities completed efficiently and effectively. We already know that coordination and overseeing the work of others is what distinguishes a managerial position from a non-managerial one. However, this does not mean that managers 
can do what they want anytime, any ware, or in any way. Instead, management involves ensuring that work activities are completed efficiently and effectively by people responsible for doing them, or at least that is what managers aspire to do (Robbins and Coulter 2012).

Moreover, Robbins et al. (2013), also defined management as the process of getting things done, effectively and efficiently, through and with other people. Several terms of this definition warrant some discussion; process, efficiently, and effectively. The terms process in the definition of management represents the primary activities that supervisors perform. We call these the management functions. According to Henri Fayol, all managers perform five management functions: plan, organized, command, coordination, and control (Dunod 1916 as cited in Robbins et al. 2013). He explained that because organizations exist to achieve some purposes, some has to define that purpose and the means for its achievement. A manager is someone. The planning functions encompass defining an organization's goals, establish an overall strategy for achieving these goals, and developing a comprehensive hierarchy of plans to integrate and coordinate activities. Managers also have to divide work into manageable components and coordinate results to achieve objectives, this is the organizing focus. Finally, when managers motivate their human capital, direct the activities of others, select the most effective communication channel, or resolve conflicts among members, they are engaging in leading.

\section{Supervision and Leadership}

The Business Dictionary (2019b) defined supervisor as the person in the firstline management who monitors and regulates human capital in their performance of assigned or delegated tasks. Supervisors are usually authorized to recommend and effect hiring, disciplining, promoting, punishing, rewarding, and other associated activities regarding the human capital in their departments. To Robbins et al. (2013) the supervisor is the key person, a person in the middle, just other human resources, and a behavioral specialist. They explained that the supervisor as a critical person serves as the critical communication link in the organization chain authority. As a person in the middle, supervisors must interact and reconcile the opposing forces and competing expectations from higher management and the rest of human capital below management. Some people see supervisors as another human resource rather than as management. The behavioral specialist role is one of the essential abilities needed by supervisors. Robbins et al. (2013), explained that the supervisor needs strong abilities in interpersonal skills and that they are looking at as a behavioral specialist.

According to Katz (1974 as cited in Robbins et al. 2013), the supervisors need necessary competencies; technical, interpersonal, conceptual, and political competencies. The technical competencies include; strategic planning, developing the organization's overall structure and culture, maintaining relations with major's customers or other organizations. The interpersonal competency is the ability to: work with people, understand their needs, communicate well, and motivate others. The conceptual competency is the mental ability to analyze and diagnose complex 
situations. These situations include seeing that the organization is a complex system of many interrelated parts and that the organization itself is part of an extensive social system that involves the community and the nation's economy. The political competency is the ability to enhance his or her power, build a power base and establish the "right" connections in the organization.

The leadership subject has so many visions to define it, due of that Kruse (2013) exposed that leadership has nothing to do with seniority or one's position in the hierarchy of a company. Leadership has nothing to do with titles, with personal attributes and is not management (Druker as cited in Kruse 2013). He said that the only definition of a leader is someone who has followers. Bennis (as cited in Kruse 2013) exposed that leadership is the capacity to translate vision into reality. Otherwise, Gates (as cited in Kruse 2013) explained that as we look ahead into the next century, leaders will be those who empower others. Maxwell (as cited in Kruse 2013) defined leadership as an influence - nothing more, nothing less. Leadership is a process of social influence which maximizes efforts of others towards the achievement of a goal (Kruse 2013). Leadership is the ability to demonstrate when somebody influences others to act in a particular way. Thought direction, encouragement, sensitivity, consideration, and support, someone inspires their followers to accept challenges and achieve goals that may be view as difficult to achieve. As a leader, the person is also someone who sees and can get the best out of others- helping them develop a sense of personal and professional accomplishment. Being a leader means building a commitment to goal attainment among those being leading, as well as a strong desire for them to continue following (Robbins et al. 2013).

\section{Household Scientific Administration and Management}

According to Encyclopaedia Brittanica.com (2019), household management refers to the various tasks and chores associated with the organization, financial management, and day-to-day operations of a home. Isabella Mary Mayson (March 12, 1836 - January 1865), universally known as Mrs. Beeton, was the author of Mrs. Beeton's Book of Household Management. In London, she is introducing to Samuel Orchard Beeton, a publisher of books and popular magazines, whom she married on 10 July 1856. Mrs. Beeton began to write articles on cooking and household management for her husband's publications. In 1859-1861, she wrote a monthly supplement to The Englishwoman's Domestic Magazine. In October 1861, the supplements published as a single volume. The Book of Household Management Comprising information for the Mistress, Housekeeper, Cook, Kitchen-Maid, Butler, Footman, Coachman, Valet, Upper and Under HouseMaids, Lady's-Maid, Maid-of-all-Work, Laundry-Maid, Nurse and Nurse-Maid, Monthly Wet and Sick Nurses, etc. etc.-also Sanitary, Medical, \& Legal Memoranda: with a History of the Origin, Properties, and Uses of all Things Connected with Home Life and Comfort (Mrs beeton.com 2012).

By the middle of the $19^{\text {th }}$ century, as part of the modern history in America, the scientific administration was everywhere, and women who have the opportunity of the formal education as Marion Talbot held firm convictions about 
education and the role of women on it. One of only a handful of women in American university administration, she advised female students at the University of Chicago to take full advantage of their academic opportunities. In assuming a new role in society, women needed both personal self-confidence and the best professional education. Talbot expected the University of Chicago to provide these in an environment in which they could be enhancing and developing. Although Talbot advocated a continuing role for women in the home, her views were not traditional. Borrowing from progressive models of efficiency and scientific management and exploiting the new technology appearing at the time, modern women had the domestic tools to escape the drudgery of the past. Marion Talbot taught that a home could be "administered" in an effective way without compromising its vital role as a cultural hearth. Talbot M. argued that equality should mean simply that and nothing else. She expected no more and no less than anyone else received. Her courses in household administration were explicitly open to both men and women, and she criticized decisions that she felt patronized any specific group (The University of Chicago Centennial Catalog 2019).

Furthermore, Shaw (1911, as cited in Ravenhill and Schiff 1911) exposed that the scientific method seeks to establish relations between isolated facts or phenomena, and the relation generally takes the form of cause and effect. $\mathrm{He}$ explained that the persons with scientific training are accustomed to examining the grounds for considering this relation of cause and effect in circumstances which are selected to exhibit the reality of the relation. From that training it becomes possible for them when confronted with circumstances presenting some difficulty, to form a better opinion as to what is the cause of the difficulty that they could if they are confronting with the same difficulty without the previous training. The fact that every person is accustomed to refer every event to some cause; if it is an illness, the occasion for contracting the illness is defining; if it is an unforeseen event in the domestic economy or if a reason is nearly always forthcoming strikes any attentive observer of human nature. Plenty of reasons offered for domestic incidents have no better ground of fact.

Moreover, Shaw (1911 as cited in Ravenhill and Schiff 1911) also talked about a good deal of the comfort of a modern house turns upon a right judgment as regards cause and effect, and therefore some preparation which will fit the household leaders to appreciate the rights and wrongs of domestic reasoning is an indispensable qualification for success. The ability for this is mostly a question of the habit of mind or training; and for our purpose, the training must include those departments of knowledge, the laws of which find daily expression in the diverse experiences of domestic life. The ultimate foundation for these laws is to being found in the study of Physics, which deals with those changes in the state of matter which stop short of the alteration of its composition of Chemistry. This deals with changes involving alteration of the composition of the substances under consideration; and of Physiology, which is the identification of the processes which take place in living animals and plants and their relation to the laws of physics and chemistry. Without knowledge of the fundamental principles of these sciences and of the methods by which those principles are establishing, it is not to 
be expecting that any person can deal adequately with the collective experiences of life.

According with Encyclopaedia Brittanica (2020), another formal pioneer in at home scientific management is Ellen Swallow Richards, (born December 3, 1842, Dunstable, Massachusetts, U.S.—died March 30, 1911, Boston, Massachusetts), American chemist and founder of the home economics movement in the United States, was educated mainly at home. She briefly attended Westford Academy and also taught school for a time. Swallow was trained as a chemist, earning an A.B. from Vassar College in 1870 and, as the first woman admitted to the Massachusetts Institute of Technology (MIT), a B.S. in 1873. Vassar accepted her master's thesis the same year. She remained at MIT for two more years of graduate studies, but she was not awarded a Ph.D. In November 1876, at her urging, the Woman's Education Association of Boston contributed funds for the opening of a Woman's Laboratory at MIT. There, as assistant director under Professor John M. Ordway, she began her work of encouraging women to enter the sciences and of providing opportunities for scientific training to capable and interested women. Courses in basic and industrial chemistry, biology, and mineralogy were taught, and through Ordway a certain amount of industrial and government consulting work was obtained. Richards published several books and pamphlets as a result of her work with the Woman's Laboratory, including The Chemistry of Cooking and Cleaning (1882; with Marion Talbot) and Food Materials and Their Adulterations (1885). From 1876 Richards was also head of the science section of the Society to Encourage Studies at Home.

In 1890, under Richards's guidance, the New England Kitchen was opened in Boston to offer to working-class families' nutritious food, scientifically prepared at low cost, and at the same time to demonstrate the methods employed. From 1894 the Boston School Committee obtained school lunches from the New England Kitchen. Richards lobbied for the introduction of courses in domestic science into the public schools of Boston, and in 1897 she helped Mary M.K. Kehew organize a school of housekeeping in the Woman's Educational and Industrial Union that was later taken over by Simmons College. In 1899 Richards called a summer conference of workers in the fledgling field of domestic science at Lake Placid, New York. Under her chairmanship the series of such conferences held over the next several years established standards, course outlines, bibliographies, and women's club study guides for the field, for which the name "home economics" was adopted. In December 1908 the Lake Placid conferees formed the American Home Economics Association, of which Richards was elected first president. She held the post until her retirement in 1910, and in that time she established the association's Journal of Home Economics. In 1910 she was named to the council of the National Education Association with primary responsibility for overseeing the teaching of home economics in public schools. Among her other published works were Home Sanitation: A Manual for Housekeepers (1887), Domestic Economy as a Factor in Public Education (1889), The Cost of Living (1899), Sanitation in Daily Life (1907), and Euthenics: The Science of Controllable Environment (1912). 
In today's family and scientific management research, Vélez-Candelario (2018), exposed the full recognition of the organizational psychology theories application and a scientific management method as a tool to develop the family organizational functionality and their socioeconomic development. She also explained that scientific administration theories and organizational psychology theories are capable instruments to apply in the household scenery to increase the efficiency in the daily life activity at the household, preventing divorce and many other psychosocial issues including at work and school performance. According to Vélez-Candelario et al. (2015), if the intra-familiar setting is not capable to administrate and develop their intelligence young human capital to work, stimulating them to be productive at school, the micro and macro economy will receive the consequences of unproductive and dysfunctional future human resources. Indeed, Vélez in her dissertation published on April 2016, as; Family, Human Capital and Industrial/Organizational Psychology, examined if the family as a social organization has the same areas to administrate and organize than the any other organize human social group. In this study tone of the main findings is that the family organization has the same administrative and organizational areas than any other human organization, like the workplace or business setting. Moreover, Vélez-Candelario et al. (2016) found that families have the four organizational areas as any other organize human group; leadership, communication, organizational culture, and environment. She also found that family leaders delineate their mission, their vision, and their goals, even when they do not create a formal organizational policies handbook.

\section{Administration and Development of the Young Human Capital at Home}

In 1964, Nobel Prize winners and University of Chicago economists Gary Becker and Theodore Schultz created the theory of human capital. Becker realized the investment in workers was no different from investing in capital equipment, which is another factor of production. Both are assets that yield income and other outputs. Becker's research focused on education. His found that $25 \%$ of the rise in U.S. per capita incomes from 1929 to 1982 was due to increases in schooling. He pointed out that the cost of education-included time as well as money. People only pursued an education if the potential income gain was greater than the cost. Becker differentiated between general and specific human capital. Specific human capital was training that would only benefit one company. General human capital would benefit the individual at any company. He found that companies would pay for specific human capital while individuals paid the general form. Becker's theory explained how investing in education benefited people, companies, and countries. That theory is supporting by research. States with the highest education scores also have the highest incomes. The top 10 states spend $50 \%$ to $100 \%$ more on education than the average, according to the National Center for Education Statistics (Amadeo 2019). To understand human capital Becker exposed that you have to go back to the family, because it is the family that is concerned about their children and try, with whatever resources they have, to promote their children's education and values. Families are the major promoters of values in any free 
society and even in not-so-free societies. The significant role of human capital in the economy means that policies toward education, health, and other investments are important partly for their implications about economic prosperity, economic growth, and income inequality (Becker 1998).

The administration and development of the human capital do not start at the workplace; it starts at home from their first day of life and continues at school below their family leader's supervision and household psychosocial, cultural and physical influences (Velez-Candelario 2011). According to Encyclopaedia Britannica (2019), Gary S. Becker (1957) is an American economist that applied the methods of economics to aspects of human behavior. Previously he considered more or less the exclusive domain of sociology, criminology, anthropology, and demography. Becker's central premise is that rational economic choices, based on self-interest, govern most aspects of human behavior - not just the purchasing and investment decisions traditionally thought to influence economic behavior. In his dissertation, published in 1957 as The Economics of Discrimination, Becker examined racial discrimination in labor markets, concluding that discrimination has costs for both the victim and the perpetrator. In Human Capital (1964), he argued that an individual's investment in education and training is analogous to a company's investment in new machinery or equipment. In studies such as $A$ Treatise on the Family (1981), Becker analyzed the household as a sort of factory, producing goods and services such as meals, shelter, and childcare. Applying theories of production to household behavior, he was able to make predictions about family size, divorce, and the role of women in the workplace. Subsequent work focused on such subjects as criminal behavior and addiction.

Human Capital and Economic Global Working Group (2012) present The Family Economics and Human Capital in Family research. They exposed that changes in cohort size alone appear to explain a significant fraction of the variation in marriage rates over time. That poverty may be starkly higher at the individual level than it is when measured at the household level only. Parents may underinvest in children not only because they are time constrained, but also because they underestimate the value of such investments. They expressed that a primary function of the family unit is the production of children, with the parental investment of both time and resources being one of the most important inputs. How much investment parents put into children has lasting consequences for the child's human capital development and future earning capacity.

\section{Purpose/Objectives of the Study}

This study was aimed to see the correlation between two variables: Family Organizational and Administrative Functionality Scale results (Velez-Candelario 2019) and the GPA at school of their Young Human Capital in the USA territory of Puerto Rico. In specific terms this study tries to: 
- Understand more precisely what is affecting the productivity levels at the school of the young human capital under the supervision of their family leaders.

- Review the quality of the FOAF Scale (Velez-Candelario, 2019) to collect mathematic data.

- Inquire in this topic of the family administrative and organizational quality management that can affect psychological and socioeconomically the members of this group at school and the rest of their socioeconomic community.

- Understand with a new perspective the productive and unproductive behavior of the young human capital at school.

\section{Research Design}

This study is a quantitative research with a co-rrelational study to analyze the relationships that exist between two specifics variables: Family Organizational and Administrative Functionality and the School Performance using the General Point Average in the group of a young human capital active at elemental and middle school. The population is select from Puerto Rico's public and private educational system; US model system (SE 2020).

\section{Research Questions}

The following research question gave direction to the study:

1. Is the Family Organizational/Administrative Functionality influencing productivity at school?

2. Is the family Organizational and Administrative functionality the Key for better academic performance at home and at school?

3. Is the correlation analysis the first step to understand how much affect the family daily household's environment the productivity at school?

\section{Hypotheses}

- Hi- Organizational and Administrative functionality at home is positively correlated with the Productivity at School of the family young human capital.

- Ho- Organizational and Administrative functionality at home has none correlation with the productivity at school of their young human capital. 


\section{The Study Scope}

This study was delimited to a sample of 265 children between 6 to 17 years old from public and private schools. The participants are from the south and center zone of the US, Territory of Puerto Rico, which has an education system based on the American model (Classbase 2018). The sample was selected by availability from volunteer families and directly from Puerto Rico's Department of Education. They have applied the FOAF Scale as a data collection and a Socio-demographic document that include the General Point Average (GPA) at school. The Family Organizational/Administrative Scale (Velez-Candelario 2019), has a $90 \%$ of overall value. The intern consistency and the Factor Analysis of it are, .89 (Cronbach's Alpha) and the Factor Analysis shows a .8 KMO (Kaiser-MayerOlkin). Using the SPSS (26 version) computer program is submitted a Pearson's Correlation formula with a correlation significance of .05 .

\section{Study Population and Sample Selection}

The population selection process was by availability within private and public system schools collaboration and a single family's student's participation. A collaboration contract with three School Principals of Puerto Rico's Department of Education was completed. A parent's consent document is submitted. The school's principals open the access of their authorized participants at school after receiving their student's adult family leader's signed consent document.

\section{The Data Collection and Pearson's Correlation Analysis Method}

The data collection was complete with a sociodemographic document; it includes the General Point Average at school of each participant. The Family Organizational and Administrative Functionality Scale (Vélez-Candelario, 2018) is applying too. This scale has a $90 \%$ of overall scale value. The Intern Consistency and the Factor Analysis of this scale are .89 (Cronbach's Alpha) and the Factor Analysis process shows a .8 KMO (Kaiser- Mayer- Olkin) by each area that the FOAF Scale measure, recognizing each one as an independent factor. For the statistical analysis, the sample is submitted in the SPSS 26 version and applies Pearson's Correlation formula.

The correlation analysis estimates a sample correlation coefficient, more specifically the Pearson product moment correlation coefficient. The sample correlation coefficient, denoted $r$, ranges between -1 and +1 and quantifies the direction and strength of the linear association between the two variables. The correlation between two variables can be positive (i.e., higher levels of one variable are associated with higher levels of the other) or negative (i.e., higher levels of one variable are associated with lower levels of the other). The sign of the correlation coefficient indicates the direction of the association. The magnitude of the correlation coefficient indicates the strength of the association. For example, a correlation of $r=$ 0.9 suggests a strong positive association between two variables, whereas a correlation 
of $r=-0.2$ suggest a weak, negative association. A correlation close to zero suggests no direct association between two continuous variables (Introduction to Correlation and Regression Analysis 2019).

The psychosocial phenomenon analysis in this study and how it emerges, Pearson's correlation formula gives us a specific metric that can be mathematically measured. To control and manage the human daily needs and behavior is pertinent to analyze it correctly and useful to received a piece of certain information that anyone can review and used as an effective instrument. This correlation analysis is the result of the Vélez et al. (2016) findings of the essential organizational and administrative areas inside the family as an organized community. The Family as a socioeconomic organization has too many things to do and manage every single day as their young human capital school productivity, school psycho-social development, family leader's governmental relations with the school administrative personnel, the household environment, neighborhoods and community influences, and many others. The family's leaders have to administrate efficiently to reach one of the harder goals, increase their young human capital productivity at school. Productivity is not an instantaneous activity in human life; it has an external or internal stimulation named motivation (Velez-Candelario 2011).

According to the Merriam-Webster dictionary (2019), motivation is a motivating force, stimulus, or influence. For Psychology Today (2019), motivation is the desire to act and move toward a goal. It is the difference between waking up before dawn to pound the pavement and lazing around the house all day. It is the crucial element in setting and attaining one's objectives - and research shows that any person can influence the motivation levels and self-control of others. Motivation might be extrinsic, whereby a person is inspiring by outside forces - other people or things that transpire. Motivation might be intrinsic, whereby the inspiration comes from within a person. Otherwise, Robbins and Coulter (2012), defined motivation as the process by which a person's efforts to energized, directed, and sustained toward attaining a goal, this definition has three key elements: energy, direction, and persistence. So become productive at school or in any other activity that has goals to achieve has to be stimulated from inside and outside.

\section{Results}

The findings show a positive correlation between FOAF and School Productivity (GPA) with a significance level of 0.01 . The Pearson correlation degree between these two variables in this study is medium, $\mathrm{r}=.341$, (Cohen 1988 as cited in Wuensh 2015). The small correlation effect size is one in which there a real effect is but which can only see through careful study. A significant effect size is an effect which is big enough, and consistent enough, that may be able to see it the naked eye (Cohen 1988 in as cited in 2007-08). The statistics analysis allowed the acceptance of the Hi (Hypothesis Investigation) confirming that exist a real and a detectable effect of correlation between FOAF and School Productivity. 
Table 1. Correlation Results (265 N) - GPA and FOAF Scale Results Correlation: in an Elementary and Middle School Grades, Private and Public Education System in the US, Territory of Puerto Rico

\begin{tabular}{|l|c|}
\hline Correlation & \\
\hline GPA Pearson Correlation & $.344^{* *}$ \\
\hline Sig. (2-tailed) & .000 \\
\hline N 265 265 & $.341^{* *} 1$ \\
\hline FOAF General \% Pearson Correlation & .000 \\
\hline Sig. (2-tailed) & \\
\hline N 265 265 & \\
\hline$* *$ Correlation is significant at the 0.01 level (2-tailed).
\end{tabular}

Table 2. 265 Sample Descriptive Statistics: Frequency

\begin{tabular}{|c|c|c|c|c|c|c|c|c|}
\hline & \multicolumn{8}{|c|}{ Statistics } \\
\hline & & $\begin{array}{c}\text { Academic } \\
\text { Level }\end{array}$ & $G P A$ & $\begin{array}{c}\text { FOAF } \\
\text { General } \\
\%\end{array}$ & Leadership & Environment & $\begin{array}{c}\text { Organizational } \\
\text { Culture }\end{array}$ & Communication \\
\hline & Valid & 265 & 265 & 265 & 265 & 265 & 265 & 265 \\
\hline & Missing & 1 & 1 & 1 & 1 & 1 & 1 & 1 \\
\hline
\end{tabular}

Frequency Table

\begin{tabular}{|l|l|c|c|c|c|}
\hline \multicolumn{7}{|c|}{ Academic Level } \\
\hline \multirow{2}{*}{} & $\begin{array}{l}\text { Elementary } \\
\text { School }\end{array}$ & 96 & 36.1 & 36.2 & $\begin{array}{c}\text { Cumulative } \\
\text { Percent }\end{array}$ \\
\cline { 2 - 6 } & Middle School & 162 & 60.9 & 61.1 & 36.2 \\
\hline \multirow{2}{*}{ Valid } & High School & 7 & 2.6 & 2.6 & 97.4 \\
\cline { 2 - 6 } & Total & 265 & 99.6 & 100.0 & 100.0 \\
\hline Missing & System & 1 & .4 & & \\
\hline Total & & 266 & 100.0 & & \\
\hline
\end{tabular}

\begin{tabular}{|l|c|c|c|c|c|}
\hline \multirow{5}{*}{} & \multicolumn{5}{|c|}{ GPA } \\
\cline { 2 - 6 } & & Frequency & Percent & $\begin{array}{c}\text { Valid } \\
\text { Percent }\end{array}$ & $\begin{array}{c}\text { Cumulative } \\
\text { Percent }\end{array}$ \\
\cline { 2 - 6 } & $4.00-3.90$ & 77 & 28.9 & 29.1 & 29.1 \\
\cline { 2 - 6 } & $3.89-3.50$ & 33 & 12.4 & 12.5 & 41.5 \\
\cline { 2 - 6 } & $3.49-3.00$ & 51 & 19.2 & 19.2 & 60.8 \\
\cline { 2 - 6 } & $2.99-2.50$ & 13 & 4.9 & 4.9 & 65.7 \\
\cline { 2 - 6 } & $2.49-3.00$ & 71 & 26.7 & 26.8 & 92.5 \\
\cline { 2 - 6 } & $2.19-2.00$ & 6 & 2.3 & 2.3 & 94.7 \\
\cline { 2 - 6 } & $1.99-1.00$ & 14 & 5.3 & 5.3 & 100.0 \\
\cline { 2 - 6 } & Total & 265 & 99.6 & 100.0 & \\
\hline Missing & System & 1 & .4 & & \\
\hline Total & & 266 & 100.0 & & \\
\hline
\end{tabular}




\begin{tabular}{|c|c|c|c|c|c|}
\hline \multirow{4}{*}{} & \multicolumn{5}{|c|}{ School Type } \\
\cline { 2 - 6 } & & Frequency & Percent & $\begin{array}{c}\text { Valid } \\
\text { Percent }\end{array}$ & $\begin{array}{c}\text { Cumulative } \\
\text { Percent }\end{array}$ \\
\cline { 2 - 6 } & $\begin{array}{c}\text { Public } \\
\text { School }\end{array}$ & 232 & 87.5 & 87.5 & 87.5 \\
\cline { 2 - 6 } & $\begin{array}{c}\text { Private } \\
\text { School }\end{array}$ & 33 & 12.5 & 12.5 & 100.0 \\
\cline { 2 - 6 } & Total & 265 & 100.0 & 100.0 & \\
\hline
\end{tabular}

\begin{tabular}{|l|c|c|c|c|c|}
\hline \multicolumn{5}{|c|}{ Leadership } \\
\hline \multirow{5}{*}{} & & Frequency & Percent & $\begin{array}{c}\text { Valid } \\
\text { Percent }\end{array}$ & $\begin{array}{c}\text { Cumulative } \\
\text { Percent }\end{array}$ \\
\cline { 2 - 6 } & $100-90 \%$ & 132 & 49.6 & 49.8 & 49.8 \\
\cline { 2 - 6 } & $89-85 \%$ & 56 & 21.1 & 21.1 & 70.9 \\
\cline { 2 - 6 } & $84-80 \%$ & 31 & 11.7 & 11.7 & 82.6 \\
\cline { 2 - 6 } & $79-70 \%$ & 30 & 11.3 & 11.3 & 94.0 \\
\cline { 2 - 6 } & $69-25 \%$ & 16 & 6.0 & 6.0 & 100.0 \\
\cline { 2 - 6 } & Total & 265 & 99.6 & 100.0 & \\
\hline Missing & System & 1 & .4 & & \\
\hline Total & & 266 & 100.0 & & \\
\hline
\end{tabular}

\begin{tabular}{|l|l|c|c|c|c|}
\hline \multicolumn{5}{|c|}{ Environment } \\
\hline \multirow{5}{*}{} & & Frequency & Percent & $\begin{array}{c}\text { Valid } \\
\text { Percent }\end{array}$ & $\begin{array}{c}\text { Cumulative } \\
\text { Percent }\end{array}$ \\
\cline { 2 - 6 } & $100-90 \%$ & 117 & 44.0 & 44.2 & 44.2 \\
\cline { 2 - 6 } & $89-85 \%$ & 54 & 20.3 & 20.4 & 64.5 \\
\cline { 2 - 6 } & $84-80 \%$ & 35 & 13.2 & 13.2 & 77.7 \\
\cline { 2 - 6 } & $79-70 \%$ & 39 & 14.7 & 14.7 & 92.5 \\
\cline { 2 - 6 } & $69-25 \%$ & 20 & 7.5 & 7.5 & 100.0 \\
\cline { 2 - 6 } & Total & 265 & 99.6 & 100.0 & \\
\hline Missing & System & 1 & .4 & & \\
\hline Total & & 266 & 100.0 & & \\
\hline
\end{tabular}

\begin{tabular}{|l|c|c|c|c|c|}
\hline \multicolumn{7}{|c|}{ Organizational Culture } \\
\hline \multirow{5}{*}{ Valid } & & Frequency & Percent & $\begin{array}{c}\text { Valid } \\
\text { Percent }\end{array}$ & $\begin{array}{c}\text { Cumulative } \\
\text { Percent }\end{array}$ \\
\cline { 2 - 6 } & $100-90 \%$ & 74 & 27.8 & 27.9 & 27.9 \\
\cline { 2 - 6 } & $89-85 \%$ & 34 & 12.8 & 12.8 & 40.8 \\
\cline { 2 - 6 } & $84-80 \%$ & 26 & 9.8 & 9.8 & 50.6 \\
\cline { 2 - 6 } & $79-70 \%$ & 79 & 29.7 & 29.8 & 80.4 \\
\cline { 2 - 6 } & $69-25 \%$ & 52 & 19.5 & 19.6 & 100.0 \\
\cline { 2 - 6 } & Total & 265 & 99.6 & 100.0 & \\
\hline Missing & System & 1 & .4 & & \\
\hline Total & & 266 & 100.0 & & \\
\hline
\end{tabular}




\begin{tabular}{|l|c|c|c|c|c|}
\hline \multicolumn{5}{|c|}{ Communication } \\
\hline \multirow{4}{*}{ Valid } & Frequency & Percent & $\begin{array}{c}\text { Valid } \\
\text { Percent }\end{array}$ & $\begin{array}{c}\text { Cumulative } \\
\text { Percent }\end{array}$ \\
\cline { 2 - 6 } & $100-90 \%$ & 100 & 37.6 & 37.7 & 37.7 \\
\cline { 2 - 6 } & $89-85 \%$ & 50 & 18.8 & 18.9 & 56.6 \\
\cline { 2 - 6 } & $84-80 \%$ & 22 & 8.3 & 8.3 & 64.9 \\
\cline { 2 - 6 } & $79-70 \%$ & 51 & 19.2 & 19.2 & 84.2 \\
\cline { 2 - 6 } & $69-25 \%$ & 42 & 15.8 & 15.8 & 100.0 \\
\cline { 2 - 6 } & Total & 265 & 99.6 & 100.0 & \\
\hline Missing & System & 1 & .4 & & \\
\hline Total & & 266 & 100.0 & & \\
\hline
\end{tabular}

\section{Significance of the Study}

The results of this study reveal the first correlated results between Family Organizational/Administrative Functionality Scale (Velez-Candelario 2019) results and the school performance using the General Point Average (GPA) of the young human capital (children). With this first study, the dilemma of increase the productivity levels at the school of the young human capital can have a new perspective and a new explanation. The family creator or leader has the responsibility to stimulate their active young human capital at school; the need to evaluate the way how they are implementing their at home organizational and administrative system is imperative. This study allows us to see the practical use of the mathematic instrument to measure the quality of the general management and organizational process at home assertively.

\section{Discussion}

After acquiring a positive correlation result between Family Administrative and Organizational Functionality performance and the GPA performance at school is essential concern about the relevance of the family daily administrative basics as one of the medullar activity that stimulates the cognitive capacity in the young human capital at school. These findings allow us to open a new vision of the power of influence of the intra-familiar management activity in their family younger human resources at school. Cohen (1988 as cited in Walker 2007-08) is very clear when explained that the small correlation effect size is one in which there is a real effect but which you can only see through careful study and, that the large effect size is an effect which is big enough or consistent, that you may be able to see with the naked eye (Cohen). It means that in a medium size correlation these two variables are influencing each other affecting the environment of the household setting and their members.

The family is not just an organized human society with the same areas to manage than any other human organization, it is the place where the youngest human resources in the actual economic development put their energies and confidence to become trained and motivated to reach their goals (Vélez, 2016). The way and style of 
the organizational and administrative process have an influence that can make a positive or a negative impact on our young human capital prosperity (VélezCandelario 2011).

\section{Conclusion}

The family leadership style, communication system, physical environment, and organizational culture are medullar areas to manage in the household as in any other human being organization. The management performance of those will define how functional will be the household human capital commitment. The high performance of these areas helps the organizational development of the group giving to the young human capital at school an enjoyable place to rest, work and produce minimizing the stress inside of it and in the school setting. Low stress helps to increase productivity in the workplace and at school. The human beings need a family with healthy and functional family management, where each one of the components feels secure, care, motivated and organize.

\section{References}

Amadeo K (2019) Human Capital and How It Shapes America's Future. Retrieved from https://bit.ly/2zG0EhM. [Accessed 02/13/2020].

Bach Pham L (2018) What Are Organizational Theories? Retrieved from https://bit.ly/ 35edCPr. [Accessed 04/16/2018].

Becker G (1998) Human Capital and Poverty. Religion \& Liberty 8(1). Retrieved from https://bit.ly/2yaccjx. [Accessed 06/18/1019].

Brunsson K (2016) A Dual Perspective on Management. Athens Journal of Business and Economics 2(3): 291-302.

Business Dictionary (2019a) Management. Retrieved from https://bit.ly/2zG12ge. [Accessed 04/24/2019].

Business Dictionary (2019b) Supervisor. Retrieved from https://bit.ly/3cYoEel. [Accessed 04/24/2019].

Chiavennato (2000) Introducción a la Teoría General de la Administración [Introduction of the General Administration Theory], $5^{\text {th }}$ ed. Méjico C.

Classbase (2018) Education System in Puerto Rico. Retrieve from https://bit.ly/2y8B6JF. [Accessed 8/14/2018].

Collions Dictionary (2019) Organizational Psychology. Retrieved from https://bit.ly/2 WmoLKb. [Accessed 04/13/19].

Encyclopaedia Bryttanica (2020) Ellen Swallow Richards. Retrieved from https://bit.ly/ 3bIcE0h. [Accessed 04/21/2020].

Encyclopaedia Britannica (2019) Gary S. Becker: America economist. Retrieved from https:// bit.ly/3f0jErf. [Accessed 04/25/2019].

Encyclopaedia Britannica (2019) Household management. Retrived from https://bit.ly/2y acJLx. [Access 04/26/2019].

Hellriegel D, Slocum JW (2009) Organizational Behavior. $1^{\text {th }}$ ed. South-Western/ Cengage Learning. 
Human Capital and Economic Global Working Group (2012) Opportunity Family Economics and Human Capital in the Family. Retrieved from https://bit.ly/2y8AJih. [Accessed 04/25/2019].

Inc. 5000 (2019) Organization Theory. Retrieved from https://bit.ly/2KL0Heh. [Access 04/29/2019].

Introduction to Correlation and Regression Analysis (2019) Pearson Correlation. Retrieved from https://bit.ly/2y8ZsD8. [Accessed 03/03/2020].

Kruse K (2013) What Is Leadership? FORBES. Retrieved from https://bit.ly/2yWNagY. [Accessed 04/24/2019].

Lareau A (2000) Unequal Childhoods: Class, Race, and Family Life, $2^{\text {nd }}$ ed., University of California Press.

Merian Webster Dictionary (2019a) Administration. Retrieved from https://bit.ly/3cSzgv2. [Accessed 04/17/2019].

Meriam-Webster Dictionary (2019b) Management.Retrieved from https://bit.ly/3d1Iwgr. [Accessed 4/24/2019].

Merry-Webster (2019) Motivation. Retrieved from https://bit.ly/3bQjNMe. [Accessed 04/11/2019].

Mrs beeton.com (2012) Mrs. Beeton's Book of Household Management. Retrieved from https://bit.ly/3bNSgL9. [Accessed 04/25/2019].

Psychology Today (2019) Motivation. Retrieved from https://bit.ly/2ySwEPc. [Accessed 04/11/19]

Rafal C (2010) Notes from Home Advantage by Annette Lareau. April, 24, 2010.Retrieved from https://bit.ly/3aPK2km. [Accessed 04/17/2020].

Ravenhill A, Schiff CJ (1911) Household Administration: Its place in the higher education of women. E.Book: \#36781. ISO-8859-1. Retrieved from https://bit.ly/ 3AqWQqB. [Accessed on 04/17/2019].

Robbins SP, Coulter M (2012) Management, $11^{\text {th }}$ ed. New Jersey: Pearson. ISBN: 978013

Robbins SP, DeCenzo DA, Wolter R (2013) Supervision Today! $7^{\text {th }}$ ed. New Jersey: Pearson. ISBN-13:978-0-13-278403-0.

Grimsley S (2019) What Is Administrative Management Theory?. Chapter 1. Lesson 5 Retrieved from https://bit.ly/2YgP5rG. [Accessed 04/17/2019].

SE (2020) Education in Puerto Rico. Retrieved from https://bit.ly/3f016Kd. [Accessed 04/21/2020].

The University of Chicago Centennial Catalog (2019) Marion Talbot: Household administration. Retrieved from https://bit.ly/3eYkV25. [Accessed 04/25/2019].

Tena-Sanchez J (2016) Raymond Boudon: An analytical social theorist. Retrieved from https://bit.ly/2zGGsMH. [Accessed 03/03/2020].

Trueman CN (2015) Pierre Bourdieu. historylearningsite.co.uk. The History Learning Site, 22. 18 Dec 2019. Retrieved from https://bit.ly/2KH52PA. [Accessed on: May 2015].

Vélez-Candelario S (2011) Construcción de Primera Escala que Mide Funcionalidad Organizacional Familiar: Para la Salud de la Gente [Construction of the first scale that Measure family organizational and administrative functionality]. XXXIII Convención Sociedad Interamericana de Psicología. Medellín, Colombia.

Vélez-Candelario S (2018) Human capital productivity: a family challenge. In Human Capital: Perspectives, Challenges and Future Directions, M Lawrence, F.Murray (eds), 145-159. New York: Nova Science Publishers.

Vélez-Candelario S (2019) Construction and validation of the first scale that measures family organizational and administrative functionality. Athens Journal of Social Sciences 6(4): 291-304. 
Vélez S, Rosario I, Méndez V, Vargas L (2016) Family, human capital and industrial/ organizational psychology. Interamerican Journal of Psychology 50(3) Retrieved from https://bit.ly/3eVsV45.[Accessed 04/29/2019].

Vélez S, Rosario I, Méndez V, Vargas L (2015) Family, human capital and ilo psychology; tending bridges. Proceedings: XXXV Interamerican Society of Psychology Congress, Page 339. PUCP, Lima, Perú. 12/16-07-2015

Walker I (2007-08) Null Hypothesis Testing and Effect Sizes. Statistics for Psychology: Making sense of our world through analysis. Retrieved from https://bit.ly/3eZ7n Dz.[Accessed 8/14/2018].

Weininger EB, Lareau A (2018) Pierre Bourdieu's Sociology of Education: Institutional Form and Social Inequality. Thomas Medvetz and Jeffrey J. Sallaz (eds). Retrieved from https://bit.ly/2YmovNT. [Accessed 04/17/2020].

Wuensch K (2015) Cohen's Conventions for small, medium and large effects. East Carolina University. Retrieved from https://bit.ly/2VL1hyW. [Access 08/14/2018]. 


\title{
Burnout Syndrome Concerning Some Personality Factors among Greek Teachers
}

\author{
By Natasha Virmozelova Angelova ${ }^{*}$ \& Konstantina Hristos Nasi ${ }^{\dagger}$
}

\begin{abstract}
Traditionally teacher's profession is associated with high levels of burnout. However the scope of the study is to differentiate the role of personality in experiencing burnout. In this paper is presented the exploration of the relationship between teacher's burnout syndrome, some personality traits and locus of control. The sample comprised of 120 teachers distributed by gender as follow 76.6\% (N=92) women and $23.3 \%(N=28)$ men. To investigate the relationship between the personality characteristics (extraversion-introversion, neuroticism, psychoticism, and loci of control) and the levels of burnout syndrome dimensions (emotional exhaustion, depersonalization, and reduced personal accomplishment) a Spearmen correlation analysis was performed. To determine which one of all personality characteristics would have the most significant influence on the burnout syndrome dimensions data were verified with eta squared coefficient. As predicted by the research suggestions the study's results showed significant correlations between teacher's burnout syndrome and personality traits - intro/extraversion, neuroticism, psychoticism, and locus of control. It has been revealed that neuroticism and intro/extroversion have the greatest effect on all three burnout dimensions (emotional exhaustion, depersonalization, and reduced personal achievements). Localization of control as variable predicting burnout showed a moderate effect on two out of three factors (emotional exhaustion and reduced personal achievements). With the lowest effect influencing, only emotional exhaustion was found to be psychoticism.
\end{abstract}

Keywords: burnout syndrome, teacher's occupational stress, personality traits, locus of control.

\section{Introduction}

In this article, the accent is on the exploration of the relationship between burnout and different personality factors amongst Greek teachers. The reason for building up such a framework lies in need of working out a kind of training programs for teachers that will allow them to get acquainted with their personality issues and to connect with personality recourses. To distinguish on which personality factors would be better to focus it was undergone literature review specifically related to the burnout and personality traits.

Generally speaking, Burnout Syndrome is referred to as prolonged exposure to high levels of occupational distress that affects in a negative way people's health (Shaufeli and Enzman 1998). Burnout is often cited as a mental adjustment disorder that provokes the development of some clinical symptoms and destroys emotion regulation when encountering unidentifiable psychosocial stressors (Shaufeli and Enzman 1998). Although there are some similarities between burnout and general stress, the main difference is on the emotional emphasis in

\footnotetext{
*Assistant Professor, South-West University "Neofit Rilski”, Bulgaria.

†PhD Student, South-West University "Neofit Rilski”, Bulgaria.
} 
experienced burnout, rather than on the physical symptoms that concern in most cases general stress (Korunka and Tement 2011).

The history of the term is usually related to Christina Maslach's theory of multidimensionality of the burnout (Maslach 1982a). Maslach described burnout syndrome as chronic exhaustion that causes negative effects on both personal and social functioning (Maslach 1982b). Maslach differentiated unidimensional models of stress when conceptualizing the multidimensional theory of burnout (Maslach 1976). Maslach and Jackson (1986), after an extensive research, stated that burnout syndrome is not simple exhaustion, rather a complex negative experience that impairs the quality of life - satisfaction, happiness, and well-being.

As mentioned before, a common characteristic of burnout's definition is that it is associated with long-term exposure to stressful circumstances (Burisch 2006). It occurs for a long period of time and is characterized by emotional devastation, negative and cynical attitudes regarding the professional environment and interpersonal relationships, a tendency for negative self-esteem, chronic dissatisfaction with the work and loss of professional motivation and achievements (Maslach and Schaufeli 1993, Maslach et al. 1996, Kokkinos 2006). Many authors stated that it is easily found in professions of human services, including health care, social work, psychotherapy, and a teacher's job (Maslach et al. 2001, Schaufeli et al. 2009).

Pines et al. (1981) also pointed burnout syndrome as a state of mind that occurs in so-called "caregiver" professions. In their study (Pines et al. 1981), they have described burnout as a gradual depletion, a "mental exhaustion" affecting various people-oriented occupational groups.

Later researches agree that burnout is noticed not only in caregiver occupations but rather can be seen in many other professions where the "triggers of burnout are excessive job demands and the employee's inability to continuously invest energy when meeting the demands" (Korunka and Tement 2011: 8). According to Stoyanov (2012), burnout syndrome is the state of "insufficiency", expressed in lack of motivation and is usually expressed through the absence of initiative for change and self-improvement.

Some conclusions drawn from Greek research regarding burnout syndrome of teachers are very interesting and they created a perfect ground for this investigation (Nasi 2018a). The overall review of different examinations revealed moderate levels of burnout among Greek teachers (Nasi 2018b). The factors contributing to teacher burnout syndrome can be divided into three categories (Pappa 2006). The first one concerns personal factors such as gender, marital status, the class they teach, and the type of academic studies. Personal characteristics and individual abilities are determinants of how a person perceives a stressful situation and how to deal with it (Stoyanova and Stoyanov 2019). The second concerns interpersonal factors such as the role other colleagues and family members play in the communication process. The third is affected by the organizational factors: school environment and the organizational requirements of education (Pappa 2006).

Although Maslach et al. (2001) pointed out that the personality factors are insignificant considering the development of burnout, there is a number of researchers that have found correlates between burnout and some personality 
factors (Stoyanova 2020, Chwalisz et al. 1992, Brouwers and Tomic 2000, Sklaavik and Sklaavik 2007, 2010, 2014, Smetackova 2017, Bono and Judge 2004).

In different examinations have been studied the relationship between common personality factors such as extraversion, neuroticism, openness to experience, agreeableness, conscientiousness, loci of control (Barutçu and Serinkan 2013, Deary et al. 1996, Hills and Norvell 1991, Mills and Huebner 1998, Endler and Parker 1990, Storm and Rotman 2003, Parkes 1986, Shaufeli and Enzman 1998). In these investigations was shown that people with neuroticism are prone to experience burnout. According to Grundy's findings (2000) neuroticism can explain around $21 \%$ of the variance in emotional exhaustion. He also proved that there is a negative relation between extraversion and burnout. In another research was concluded that occupational burnout affects many more men than women, and teachers with work experience longer than 15 years, than these having between 6 and 15 years at school (Szeliga-Kowalczyk 2015). People with pronounced levels of burnout are found to be worried, uneasy, and they overreact, overthink. They are emotionally unstable and often are suppressed and prone to depressive mood (Bono and Judge 2004). On the contrary, the persons with emotion-regulation ability have high emotional response thresholds, quickly regaining their baseline after emotional excitement (Smetackova 2017, Brackett et al. 2010, Gross 2002). Emotion-regulation heightens the resilience and self-efficacy (Smetackova 2017). Overall, teachers with emotion-regulation can act as balanced, have good selfcontrol and have better possibilities for adaptation, especially in exhaustive situations. Emotion-regulation is a quality that must necessarily be adopted by a teacher as it includes restraint and control of emotions in conflict situations; overcoming stressful states, lack of neurotic outbursts, etc (Mavrodiev and Dimitrova 2016).

Predispositions for the teachers` burnout are increased anxiety, introvertness, idealism, over-enthusiasm, workaholism, over-motivation and ambition, high expectations, internal locus of control (Bevis 2008). Amongst all personality factors, locus of control is the one that is very interesting to be investigated. Loci of control is a generalized expectation between the dependence of support by external factors on one hand and one's own personal efforts on the other hand (Joe 1971). Investigations in this field have shown that the locus of control is the second most important prognostic factor for achievements and coping in distressful situations (Pajares and Miller 1994). Burnout is found to be higher in individuals with external localization of control, than in individuals with an internal localization of control (Korunka and Tement, 2011, Tsenova 2005).

Several studies have confirmed a moderate correlation between self-efficacy and burnout amongst teachers (Chwalisz et al. 1992, Brouwers and Tomic 2000, Sklaavik and Sklaavik 2007, 2010, 2014). However, the teacher's personality and the level of their psychological resilience have the most decisive part to play in the educational system as they come into daily contact and communication with the students and are the ones who have the greatest responsibility for either the success or the failure of the students' progress (Nasi 2018a).

Aims and Hypotheses 
The main goal of the study is to explore the relationship between teacher's burnout syndrome and some personality traits. The intention of this investigation was to determine which one of all personality characteristics (extraversionintroversion, neuroticism, psychoticism, loci control) has the biggest influence on the burnout syndrome scales (emotional exhaustion, depersonalization, and reduced personal accomplishment).

H1: The main predisposition in this research is that personality factors such as extroversion, neuroticism, psychoticism and loci of control would correlate significantly with any of the burnout syndrome scales: emotional exhaustion, depersonalization, and reduced personal accomplishment.

$\mathrm{H} 2$ : Consistent with the literature review, the second hypothesis is that extroversion and neuroticism would have the biggest influence on the levels of burnout dimensions (emotional exhaustion, depersonalization, and reduced personal accomplishment), followed by loci of control and psychoticism.

\section{Methodology of Research}

\section{Background}

The research was carried out on the territory of the Republic of Greece in 2019. To guarantee the confidentiality of the research participants were told the study is anonymous and they filled in a consent declaration. The examination was done in small groups, around 15 persons attended at each group. The research questionnaires were handed to every person who should fill them out at that very moment and return them back after finishing. There was a detailed instruction on each instrument.

\section{Participants}

Three questionnaires and a declaration of consent were handed to 120 Greek teachers. Because of the small sample (only 120 teachers), the research is not at all nationally representative. The age of participants was ranged between 23 and 58 years of age $(M=39.6 S D=10.3)$.

As common in the teacher's profession, most of the teachers are women and that is to be seen from the sample that comprised $76.6 \%(\mathrm{~N}=92)$ women and $23.3 \%(\mathrm{~N}=28)$ men. They were distributed according to their state as permanent teachers $57.5 \%(\mathrm{~N}=69)$ from them $66.7 \%(\mathrm{~N}=46)$ female and $33.3 \%(\mathrm{~N}=23)$, and substitute teachers $42.5 \%(\mathrm{~N}=51)$ from them $90 \%(\mathrm{~N}=46)$ were women and $9.8 \%$ $(\mathrm{N}=5)$ were men.

When exploring teacher's burnout, one of the most important characteristics is the ages of working experience as a teacher. It was ranged between 1 and 35 years 
of experience with $M=14.7$ and $S D=9.9$. All teachers are ranged in four groups, as could be seen from the next Table 1 .

Table 1. Ages of Work Experience among Teachers, $N=120$

\begin{tabular}{|l|c|c|}
\hline Ages of work experience & N & \% \\
\hline $1-5$ & 34 & 28.3 \\
\hline $6-10$ & 13 & 10.8 \\
\hline $11-15$ & 16 & 13.3 \\
\hline More than 16 & 57 & 47.5 \\
\hline Total & 120 & 100 \\
\hline
\end{tabular}

According to their educational degree, the participants were distributed into three groups: bachelor, master, and Ph.D. So that, $60 \%$ of them $(\mathrm{N}=72)$ are bachelors, $36.6 \%(\mathrm{~N}=44)$ have a master degree and 3.3\% $(\mathrm{N}=4)$ have a Ph.D. diploma.

\section{Research Instruments}

Maslach's Burnout Syndrome Inventory consists of 22 questions answered by Likert point scale ranged from 0 - never happened to me, 1 - extremely rarely happened to me, 2 - rarely happened to me, 3 - sometimes happens to me, 4 often happens to me, 5- very often happens to me, 6 - every day happens to me. Items are distributed into three scales: Emotional Exhaustion, Depersonalization and Reduced Personal Accomplishment (the last scale is reversed: the low scores are the positive ones). Bartletts` test $X 2(231)=163.5 ; \mathrm{p}<.001$ and $\mathrm{KMO}=.871$ demonstrated a very good results for the factor analysis. For the reliability statistic of the inventory was counted a Cronbach`s alfa $=.792(M=62.6 S D=14.3)$ and for the Emotional Exhaustion scale a Cronbach`s alfa $=.910(M=20.5 S D=$ 12.1), Depersonalization scale showed a Cronbach`s alfa $=.848(M=4.7 S D=$ 5.2), for the last one scale Reduced Personal Accomplishment was demonstrated a Cronbach`s alfa $=.827(M=37.3 S D=6.8)$

Rotter's Locus of Control Scale comprised 29 item pairs. The participants should choose one of the two items in each couple. A high score gives External Loci of Control and a low score - Internal Locus of Control. Bartletts` test $X 2$ $(406)=105.3 ; \mathrm{p}<.001$ and $\mathrm{KMO}=.745$ demonstrated a very good results for the factor analysis. The reliability statistic of the inventory counted a low Cronbach's alfa $=.144(M=43.4 S D=2.6)$. The low scores are related to an internal locus of control and the high scores are the external locus of control.

The short-form of Eysenck Personality Questionnaire consists of 48 questions that should be answered YES/NO. There are four scales: Extroversion-Introversion (with 12 items) where the low scores indicate introverted attitude and high scores extroverted; Neuroticism (with 12 items); Psychotism (with 12 items) and Lie scale (with 12 items) to prove validity of the test. Bartletts` test $X 2(1128)=289.4$; $\mathrm{p}<.001$ and $\mathrm{KMO}=.730$ demonstrated a very good results for the factor analysis. For the reliability statistic of the inventory was counted a Cronbach`s alfa $=.696$ $(M=71.8 S D=5.1)$ and for the Extro-Introversion scale a Cronbach`s alfa $=.688$ $(M=16 S D=2.3)$, Neuroticism scale showed a Cronbach`s alfa $=.833(M=$ 
$19 S D=3.3)$, for the scale Psychoticism was presented a very low scores on Cronbach`s alfa $=.108(M=15.5 S D=1.1)$ and the last one Lie scale had a moderate Cronbach`s alfa $=.473(M=19.6 S D=1.9)$.

\section{Measures}

An SPSS 16 statistical package was used and performed analyzes were: Spearman's rank correlation coefficient or Spearman's rho is a nonparametric measure of rank correlation (statistical dependence between the ranks of two variables (Wayne 1990).

Eta squared $(\eta 2)$ measure was used to prove the hypothesis about the effect size explained through the ratio of variance in the dependent variable by a predictor. According to Pierce et al. (2004) the ranges of the effect size are:

$$
\begin{aligned}
& .01 \sim \text { small } \\
& .06 \sim \text { medium } \\
& >.14 \sim \text { large. }
\end{aligned}
$$

\section{Research Results}

In the following Table 2 , it could be seen that $35 \%$ of the people had low emotional exhaustion levels, $44 \%$ showed middle level, and $21 \%$ high level of emotional exhaustion. Sixty-two percent of the researched people declared low degrees on depersonalization, $33 \%$ had a moderate level, and a tiny percent and only $5 \%$ presented high grades on this scale.

Only a small number of participants $3 \%$ showed low levels on the scale reduced personal accomplishment here should be mentioned that this scale is a reversed and the low levels on reduced personal accomplishment means that these persons strive to high professional performance. Half of the people (51\%) declared moderate levels on reduced personal accomplishment. Finally, unfortunately, a significant number of $46 \%$ of a sample showed high levels on the scale reduced personal accomplishment.

Table 2. Distribution of the Percents of Examined People onto the Levels of the Variables Emotional Exhaustion, Depersonalization, Reduced Personal Accomplishment, $N=120$

\begin{tabular}{|l|c|c|c|}
\hline Levels & $\begin{array}{c}\text { Emotional } \\
\text { Exhaustion }\end{array}$ & Depersonalization & $\begin{array}{c}\text { Reduced Personal } \\
\text { Accomplishment }\end{array}$ \\
\hline Low & $35 \%$ & $62 \%$ & $3 \%$ \\
\hline Middle & $44 \%$ & $33 \%$ & $51 \%$ \\
\hline High & $21 \%$ & $5 \%$ & $46 \%$ \\
\hline Total & $100 \%$ & $100 \%$ & $100 \%$ \\
\hline
\end{tabular}

As seen from Table 3, 88.3\% of the participants were internals, and only $11.7 \%$ are externals on loci of control. The majority of the teachers, 66.7\%, showed extroverted attitudes, and only $33.3 \%$ were introverted persons. Concerning neuroticism, $14.2 \%$ of the whole sample of teachers was with high 
levels of neuroticism. It is also essential that $16.7 \%$ of the researched persons had high levels of psychoticism.

Table 3. Distribution of the examined variables (Internal/External Locus of Control, Extra/Introversion, Neuroticism, Psychoticism upon Emotional Exhaustion, Depersonalization, Reduced Personal Accomplishment) in the researched sample $N=120$

\begin{tabular}{|c|c|c|c|c|}
\hline \multirow[b]{2}{*}{ Variables } & \multicolumn{3}{|c|}{ Levels of Emotional Exhaustion } & \multirow[b]{2}{*}{ Total } \\
\hline & Low & Middle & High & \\
\hline Internal Locus of Control & $34.2 \%$ & $42.5 \%$ & $11.6 \%$ & $88.3 \%$ \\
\hline External Locus of control & $.8 \%$ & $1.7 \%$ & $9.2 \%$ & $11.7 \%$ \\
\hline Extraversion & $19.2 \%$ & $28.3 \%$ & $19.2 \%$ & $66.7 \%$ \\
\hline Introversion & $15.8 \%$ & $15.8 \%$ & $1.7 \%$ & $33.3 \%$ \\
\hline \multicolumn{5}{|l|}{ Neuroticism } \\
\hline Low & $.8 \%$ & $1.7 \%$ & $8.3 \%$ & $10.8 \%$ \\
\hline Middle & $26.7 \%$ & $35.8 \%$ & $12.5 \%$ & $75 \%$ \\
\hline High & $7.5 \%$ & $6.7 \%$ & 0 & $14.2 \%$ \\
\hline \multicolumn{5}{|l|}{ Psychoticism } \\
\hline Low & 0 & $2.5 \%$ & $4.2 \%$ & $6.7 \%$ \\
\hline Middle & $27.5 \%$ & $34.2 \%$ & $15 \%$ & $76.7 \%$ \\
\hline High & $7.5 \%$ & $7.5 \%$ & $1.7 \%$ & $16.7 \%$ \\
\hline & \multicolumn{3}{|c|}{ Levels of Depersonalization } & \\
\hline Variables & Low & Middle & High & Total \\
\hline Internal Locus of Control & $59.2 \%$ & $26.7 \%$ & $2.5 \%$ & $88.3 \%$ \\
\hline External Locus of control & $2.5 \%$ & $6.7 \%$ & $2.5 \%$ & $11.7 \%$ \\
\hline Extraversion & $36.7 \%$ & $25 \%$ & $5 \%$ & $66.7 \%$ \\
\hline Introversion & $25 \%$ & $8.3 \%$ & 0 & $33.3 \%$ \\
\hline \multicolumn{5}{|l|}{ Neuroticism } \\
\hline Low & $4.2 \%$ & $3.3 \%$ & $3.3 \%$ & $10.8 \%$ \\
\hline Middle & $45.8 \%$ & $28.3 \%$ & $.8 \%$ & $75 \%$ \\
\hline High & $11.7 \%$ & $1.7 \%$ & $.8 \%$ & $14.2 \%$ \\
\hline \multicolumn{5}{|l|}{ Psychoticism } \\
\hline Low & $2.5 \%$ & $3.3 \%$ & $.8 \%$ & $6.7 \%$ \\
\hline Middle & $50.8 \%$ & $21.7 \%$ & $4.2 \%$ & $76.7 \%$ \\
\hline High & $8.3 \%$ & $8.3 \%$ & 0 & $16.7 \%$ \\
\hline \multirow[t]{2}{*}{ Variables } & \multicolumn{3}{|c|}{$\begin{array}{c}\text { Levels of Reduced Personal } \\
\text { Accomplishment }\end{array}$} & \\
\hline & Low & Middle & High & Total \\
\hline Internal Locus of Control & $1.7 \%$ & $41.7 \%$ & $45 \%$ & $88.3 \%$ \\
\hline External Locus of control & $1.7 \%$ & $9.2 \%$ & $.8 \%$ & $11.7 \%$ \\
\hline Extraversion & $2.5 \%$ & $40.8 \%$ & $23.3 \%$ & $66.7 \%$ \\
\hline Introversion & $.8 \%$ & $10 \%$ & $22.5 \%$ & $33.3 \%$ \\
\hline \multicolumn{5}{|l|}{ Neuroticism } \\
\hline Low & $.8 \%$ & $8.3 \%$ & $1.7 \%$ & $10.8 \%$ \\
\hline Middle & $1.7 \%$ & $39.2 \%$ & $34.2 \%$ & $75 \%$ \\
\hline High & $.8 \%$ & $3.3 \%$ & $10 \%$ & $14.2 \%$ \\
\hline \multicolumn{5}{|l|}{ Psychoticism } \\
\hline Low & 0 & $5 \%$ & $1.7 \%$ & $6.7 \%$ \\
\hline Middle & $2.5 \%$ & $39.2 \%$ & $35 \%$ & $76.7 \%$ \\
\hline High & $.8 \%$ & $6.7 \%$ & $9.2 \%$ & $16.7 \%$ \\
\hline
\end{tabular}


To get a more precise point of view in this research about the connection between burnout syndrome and some personality traits, a Spearman`s correlation analysis was performed.

The empirical data showed there were weak to moderate correlations between the researched variables. So it could be said there is a connection between emotional exhaustion and neuroticism $\mathrm{r}_{\mathrm{s}}(120)=380 ; \mathrm{p}<.005$; psychoticism $\mathrm{r}_{\mathrm{s}}$ $(120)=235 ; \mathrm{p}=.010 ;$ intro/extroversion $\mathrm{r}_{\mathrm{s}}(120)=198 ; \mathrm{p}=.031$; and locus of control $r_{\mathrm{s}}(120)=.210 ; \mathrm{p}=.021$. Emotional exhaustion is the central factor of burnout syndrome and this is supported by the results given here. All personality traits and locus of control connect significantly with this variable.

Next scale from Maslach`s burnout syndrome inventory is depersonalization and it was found that it correlated negatively with neuroticism $r_{\mathrm{s}}(120)=-251 ; \mathrm{p}=$ .006 and intro/extraversion scale $\mathrm{r}_{\mathrm{s}}(120)=244 ; \mathrm{p}=.007$.

The last scale Reduced Personal Accomplishment showed significant correlations with neuroticism $r_{s}(120)=.262 ; p=.004$, introversion/extroversion $r_{s}$ $(120)=-.243 ; p=.008$, and internal locus of control $r_{s}(120)=-.228 ; p=.012$. The correlation between reduced personal accomplishment and neuroticism shows that people high on neuroticism have low on scale Reduced Personal Accomplishment. Logically people who are introverted and internals could be described as demanding, strict, and severe to themselves when they do not achieve the goals and blame themselves for low personal accomplishment. A teacher`s behavior when experiencing burnout is determined by sort of withdrawal and keeping mental distance and delaying the duties.

Table 4. Correlation analysis (Spearman's rho) Showing the Relation between the Levels of variables: Emotional Exhaustion, Depersonalization, Reduced Personal Accomplishment, Locus of Control, Extra/Introversion, Neuroticism, Psychoticism, $N=120$

\begin{tabular}{|l|c|c|c|c|c|}
\hline \multirow{1}{*}{ Variables } & & Neuroticism & Psycoticism & $\begin{array}{c}\text { Introversion/ } \\
\text { Extroversion }\end{array}$ & $\begin{array}{c}\text { Locus of } \\
\text { Control }\end{array}$ \\
\hline \multirow{2}{*}{$\begin{array}{l}\text { Emotional } \\
\text { Exhaustion }\end{array}$} & $\mathrm{r}_{\mathrm{s}}$ & .380 & .235 & .198 & .210 \\
\cline { 2 - 6 } & $\mathrm{p}$ & .000 & .010 & .031 & .021 \\
\cline { 2 - 6 } & $\mathrm{N}$ & 120 & 120 & 120 & 120 \\
\hline \multirow{3}{*}{ Depersonalization } & $\mathrm{r}_{\mathrm{s}}$ & -.251 & .000 & .244 & .148 \\
\cline { 2 - 6 } & $\mathrm{p}$ & .006 & .996 & .007 & .106 \\
\cline { 2 - 6 } & $\mathrm{N}$ & 120 & 120 & 120 & 120 \\
\hline \multirow{2}{*}{$\begin{array}{l}\text { Reduced Personal } \\
\text { Accomplishment }\end{array}$} & $\mathrm{r}_{\mathrm{s}}$ & .262 & .104 & -.243 & -.228 \\
\cline { 2 - 6 } & $\mathrm{p}$ & .004 & .256 & .008 & .012 \\
\cline { 2 - 6 } & $\mathrm{N}$ & 120 & 120 & 120 & 120 \\
\hline
\end{tabular}

As suggested in the main hypothesis, the high levels of neuroticism, and psychoticism, the introversion/extroversion and loci of control, correlated significantly with any of the burnout syndrome scales: emotional exhaustion, depersonalization, and reduced personal accomplishment. All three scales that are content of the burnout syndrome inventory according to the Maslach`s Multidimensional theory, correlated significantly with the high levels of 
neuroticism, psychoticism, and also with the scales intro/extroversion and internal/external localization of control.

In order to understand how the three Maslach`s scales get influenced by the personality traits was counted eta squared coefficient and it showed as presented in the next Table 4, significant results between almost all variables.

Table 4. Eta squared and Fisher's criterion Showing the Relation between the Levels of variables Emotional Exhaustion, Depersonalization, Reduced Personal Accomplishment, Internal/External Locus of Control, Extral Introversion, Neuroticism, Psychoticism $N=120$

\begin{tabular}{|c|c|c|c|c|c|c|c|c|c|c|c|c|c|c|c|c|}
\hline \multirow[t]{2}{*}{ Variables } & \multicolumn{4}{|c|}{ Neuroticism } & \multicolumn{4}{|c|}{ Psycoticism } & \multicolumn{4}{|c|}{$\begin{array}{l}\text { Introversion/ } \\
\text { Extroversion }\end{array}$} & \multicolumn{4}{|c|}{ Locus of Control } \\
\hline & $\eta 2$ & $F$ & $d f$ & $p$ & $\eta 2$ & $F$ & $d f$ & $p$ & $\eta 2$ & $F$ & $d f$ & $p$ & $\eta 2$ & $F$ & $d f$ & $p$ \\
\hline $\begin{array}{l}\text { Emotional } \\
\text { Exhaustion }\end{array}$ & .183 & 13.074 & $\begin{array}{c}2 \\
117 \\
\end{array}$ & $<.005$ & .087 & 5.567 & $\begin{array}{c}2 \\
117 \\
\end{array}$ & $<005$ & .040 & 4.859 & \begin{tabular}{|c|}
1 \\
118 \\
\end{tabular} & $<.005$ & .043 & 5.251 & $\begin{array}{c}1 \\
118 \\
\end{array}$ & $<005$ \\
\hline $\begin{array}{l}\text { Deperso- } \\
\text { nalization }\end{array}$ & .094 & 6.047 & \begin{tabular}{|c|}
2 \\
117
\end{tabular} & $<005$ & .025 & 1.525 & $\begin{array}{c}2 \\
117\end{array}$ & .222 & .076 & 9.692 & \begin{tabular}{|c|}
1 \\
118 \\
\end{tabular} & $<.005$ & .023 & 2.733 & $\begin{array}{c}1 \\
118\end{array}$ & .101 \\
\hline $\begin{array}{l}\text { Reduced } \\
\text { Personal } \\
\text { Accomplishment }\end{array}$ & .065 & 4.055 & $\begin{array}{c}2 \\
117\end{array}$ & $<005$ & .010 & .566 & $\begin{array}{c}2 \\
117\end{array}$ & .569 & .051 & 6.352 & \begin{tabular}{|c|}
1 \\
118 \\
\end{tabular} & $<.005$ & .047 & 5.785 & \begin{tabular}{|c|}
1 \\
118
\end{tabular} & $<005$ \\
\hline
\end{tabular}

The displayed data revealed that neuroticism has a moderate effect on the scale reduced personal accomplishment $\eta^{2}=.065 \mathrm{~F}(2,117)=4.055 \mathrm{p}<.005$ and large effect on emotional exhaustion $\eta^{2}=.183 \mathrm{~F}(2,117)=13.074 \mathrm{p}<.005$ and on depersonalization $\eta^{2}=.094 \mathrm{~F}(2,117)=6.047 \mathrm{p}<.005$.

Psychoticism showed a large effect on emotional exhaustion $\eta^{2}=.087$ $\mathrm{F}(2,117)=5.567 \mathrm{p}<.005$ but did not present any significant results as an influence on depersonalization and on reduced personal accomplishment.

Intro/extroversion scale demonstrated moderate effect on emotional exhaustion $\eta^{2}=.040 \mathrm{~F}(1,118)=4.859 \mathrm{p}<.005$, and large effect on depersonalization $\eta^{2}=.076 \mathrm{~F}(1,118)=9.692 \mathrm{p}<.005$ and reduced personal accomplishment $\eta^{2}=.051 \mathrm{~F}(1,118)=6.352 \mathrm{p}<.005$. After neuroticism this scale seems to be next influential on the burnout syndrome dimensions.

As it is seen in previous table Locus of control is a predictor of burnout syndrome in moderating two out of three scales of burnout inquiry and these are emotional exhaustion $\eta^{2}=.043 \mathrm{~F}(1,118)=5.251 \mathrm{p}<.005$ and reduced personal achievement $\eta^{2}=.047 \mathrm{~F}(1,118)=5.785 \mathrm{p}<.005$.

\section{Discussion}

As predicted in hypotheses, and supported by the literature, the results of this study showed correlations between teacher's burnout syndrome and some personality traits (neuroticism, psychoticism, intro/extraversion, and locus of control). It was also demonstrated that neuroticism and introversion/extroversion are the personality traits influencing the levels of all three burnout dimensions. Localization of control as burnout predictor showed moderate effects on two 
out of three factors (emotional exhaustion and reduced personal achievements). And psychoticism was found to affect only emotional exhaustion.

The strongest correlation was between neuroticism and emotional exhaustion. Neuroticism, as pointed out by Eysenck, is about experiencing negative affects when facing minor stressors. So that, people who get easily upset, anxious, or disappointed are prone more often to emotional exhaustion than do the others. Our findings asserted earlier studies (Bakker et al. 2006, Deary et al. 1996, Francis et al. 2004, Hetland et al. 2007, LePine et al. 2004, Piedmont 1993, Zellars et al. 2000). As a whole from this statistics and supported from other researches (Azeem 2013) could be said the neuroticism is moderating all three scales from Maslach's inventory and as an interpretation here is that teachers with neuroticism are prone to experience high levels of emotional exhaustion, depersonalization and reduced personal accomplishment. Some researchers declared a negative connection between emotional exhaustion and extraversion (Gonzalez-Roma et al. 2006, Magnano et al. 2015), but there are also other investigations that have described the energy of extraversion as a stable predictor of emotional exhaustion (Gustafsson et al. 2009). However, the literature is not consistent about this connection. Extraverted people are sociable and as mentioned before, emotional exhaustion is to be met when people go in professional interaction with very high expectations.

Depersonalization was found in many cases when people are experiencing burnout syndrome (Demerouti et al. 2001). There is a conception that the two dimensions intro/extroversion and neuroticism define four types. An explanation here is to be found in the fact that teachers are usually communicative and extroverted people. Interpreting this result could be said that those teachers with depersonalization and extroverteness tend to have much more conversations with co-workers instead of doing their duties (Cordes and Dougherty 1993).

It was demonstrated that internal localization of control, introversion and neuroticism showed a connection with high reduced personal achievements and with burnout syndrome as a whole. Findings from other authors also supported the results presented here (Akça and Yaman 2010). People who have high levels on this scale feel a lack of progress and lose their motivation doing their best for further achievements (Azeem 2013, George and Brief 2004, Wright and Cropanzano 1998).

Many other authors (Connor-Smith and Flachsbart 2007, George and Brief 2004, Jex et al. 2001) stated that the individual's coping mechanisms are influenced by people's personality traits and the coping behavior is also grounded on the environmental factors that supported specific attitudes. An important component for a better professional attitude to the pedagogical work is the formation of all these personal qualities that ensure sustainability, successful adaptation and future perspectives. The adjustment to the educational environment and adaptation to pedagogical activity is an important problem related to the activity of the teachers, their personality and attitudes towards their profession and professional improvement (Mavrodiev 2008). 


\section{Conclusions}

Teaching is an emotionally, physically, and mentally demanding job. Long hours of working time, children with behavioral disorders, teenagers and lack of support from educational leadership lead both primary and secondary school teachers in losing their enthusiasm and often the teaching process is considered to be extremely stressful. It affects the adaptation to the social, physical and professional environment. Disappointment from the experienced failure in the workplace manifests in different ways in accordance to the personality type and being facilitated to rise to critical levels to burnout.

Psychological problems in the teaching profession very often are related to the teacher's personality, as well as with the nature and the specifics of teacher's work.

All personality aspects examined and presented in this study showed that the type of connecting the world outside (through introverted or extroverted attitudes), the way of attributing the failure (internal or external), the emotional tense a person is inclined to react with to the stimuli (neuroticism), the abnormal type of reaction to different stimuli (psychoticism) were found to be influential to a different extent to the experienced level of emotional exhaustion, depersonalization and reduced personal accomplishment.

It has been revealed that neuroticism and introversion/extroversion are those personality traits with the greatest effect on all three burnout dimensions. Localization of control as variable predicting burnout showed moderate effects on two out of three factors (emotional exhaustion and reduced personal achievements). With the lowest effect influencing, only emotional exhaustion was found to be psychoticism.

Traditionally teacher's profession is associated with high levels of distress and experienced burnout. So, teachers more often than do other professionals are prone to feel mentally and emotionally exhausted, less motivated for doing their work and improving themselves for future achievements. All this, on a personal level, affects in a negative way the process of self-knowledge and the development of positive coping strategies and personality skills that could ensure a sustainable and flexible personality structure. It would be beneficial for all teaching staff to participate in training programs that couch resilience and attach importance and meaning to the teacher's profession.

\section{Limitation of the Study}

There were several limitations in conducting this research. One of them was the small group sample: the sample size and spread did not adequately represent the research problem among Greek teachers. Finally, further researches and reflections need to be explored, adding other factors such as well-being, loneliness, aggression, etc. they might give a more deep understanding of the way people experience burnout. 


\section{References}

Akça F, Yaman B (2010) The Effects of internal-external locus of control variables on burnout levels of teachers. Procedia - Social and Behavioral Sciences 2(2): 39763980 doi: $10.1016 /$ j.sbspro.2010.03.626

Azeem SM (2013) Conscientiousness, Neuroticism and Burnout among Healthcare Employees. International Journal of Academic Research in Business and Social Sciences 3(7). doi: 10.6007/IJARBSS/v3-i7/68

Bakker AB, van Der Zee K I, Lewig KA, Dollard MF (2006) The relationship between the big five personality factors and burnout: A study among volunteer councilors. The Journal of Social Psychology 146: 31-50.

Barutçu E, Serinkan C (2013) Burnout Syndrome of Teachers: An Empirical Study in Denizli in Turkey. Procedia - Social and Behavioral Sciences 89: 318-322.

Bevis KA (2008) Teacher Burnout: Locus of Control and its Correlation to Teacher Burnout and Job Satisfaction. Theses, Dissertations and Capstones. Paper 466.

Bono JE, Judge TA (2004) Personality and Transformational and Transactional Leadership: A Meta-Analysis. Journal of Applied Psychology 89: 901-910. http://dx.doi.org/10. 1037/0021-9010.89.5.901

Brackett MA, Palomera R, Mojsa-Kaja J, Reye MR, Salovey P (2010) Emotion regulation ability, burnout, and job satisfaction among British secondary school teachers. Psychology in the Schools 47(4): 406-417.

Brouwers A, Tomic W (2000) A longitudinal study of teacher burnout and perceived selfefficacy in classroom management. Teaching and Teacher education 16(2): 239-253.

Burisch M (2006) Das Burnout-Syndrom: Theorie der inneren Erschöpfung [The Burnout-Syndrome: A Theory of inner Exhaustion]. Heidelberg: Springer Medizin Verlag.

Chwalisz K, Altmaier EM, Russell DW (1992) Causal attributions, self-efficacy cognitions, and coping with stress. Journal of Social and Clinical Psychology 11(4): 377-400.

Connor-Smith JK, Flachsbart C (2007) Relations between personality and coping: A metaanalysis. Journal of Personality and Social Psychology 93: 1080-1107.

Cordes CL, Dougherty TW (1993) A review and an integration of research on job burnout. Academy of Management Review 18: 621-656.

Deary IJ, Blenkin H, Agius RM, Endler NS, Zeally H, Wood R (1996) Models of jobrelated stress and personal achievement among consultant doctors. British Journal of Psychology 87: 3-29.

Demerouti E, Bakker AB, Nachreiner F, Schaufeli WB (2001) The job demands-resource model of burnout. Journal of Applied Psychology 86: 499-512.

Endler NS, Parker JDA (1990) Multidimensional assessment of coping: A critical evaluation. Journal of Personality and Social Psychology 58: 844-854.

Francis LJ, Louden SH, Rutledge CJF (2004) Burnout among Roman Catholic parochial clergy in England and Wales: Myth or reality? Review of Religious Research, 46, 519

George JM, Brief AP (2004) Personality and work-related distress. In B Schneider, DB Smith, (Eds), Personality and Organization, 193-219. Mahwah, NJ: Lawrence Erlbaum Associates.

González-Romá V, Schaufeli WB, Bakker AB, Lloret S (2006) Burnout and Work Engagement: Independent Factors or Opposite Poles? Journal of Vocational Behavior 68(1):165-74. doi: 10.1016/j.jvb.2005. 01.003

Gross JJ (2002) Emotion regulation: Affective, cognitive, and social consequences. Psychophysiology 39(3): 281-291. 
Grundy SE (2000) Perceived work-related stressors, personality, and degree of burnout in firefighters. Dissertation Abstracts International: Section B: The Sciences and Engineering, 61(3B): 1685.

Gustafsson G, Persson B, Eriksson S, Norberg A, Strandberg G (2009) Personality Traits among Burnt out and Non-Burnt out Health-Care Personnel at the Same Workplaces: A Pilot Study. International Journal of Mental Health Nursing 18(5):336-48. doi: 10.1111/j.1447-0349.20 09.00623.x

Hetland H, Sandal GM, Johnsen TB (2007) Burnout in the information technology sector: Does leadership matter? European Journal of Organizational Psychology 16: 58-75.

Hills H, Norvell N (1991) An examination of hardiness and neuroticism as potential moderators of stress outcomes. Behavioral Medicine 17(1): 31-38.

Jex S, Bliese PD, Buzzell S, Primeau J (2001) The impact of self-efficacy on stressorstrain relations: Coping style as an exploratory mechanism. Journal of Applied Psychology 86: 401-409.

Joe VC (1971) Review of the internal-external control construct as a personality variable. Psychological Reports 28: 619-640.

Kokkinos CM (2006) Factor structure and psychometric properties of the Maslach Burnout Inventory. Educators Survey among elementary and secondary school teachers in Cyprus. Stress and Health 22(1): 25-33.

Korunka C, Tement S (2011) Burnout Intervention Training for Managers and Team Leaders Burnout: Definition, recognition and prevention approaches.

LePine JA, LePine MA, Jackson CL (2004) Challenge and hindrance stress: Relationships with exhaustion, motivation to learn and learning performance. Journal of Applied Psychology 89: 883-891.

Magnano P, Paolilo A, Barrano C (2015) Relationships between Personality and BurnOut: An Empirical Study with Helping Professions' Workers. International Journal of Humanities and Social Science Research 1: 10-19.

Maslach C (1976) Burned-out. Human Behavior (5)6-22.

Maslach C (1982a) Burnout: The cost of caring. Englewood Cliffs, NJ: Prentice Hall.

Maslach C (1982b) Understanding burnout: Defintional issues in analizing a complex phenomenon. In W S Paine (ed), Job, Stress and Burnout, 29-40. Beverly Hills, CA: Sage.

Maslach C, Schaufeli WB, Leiter MP (2001) Job burnout. The Annual Review of Psychology (52): 397-422.

Maslach C, Jackson SE (1986) Maslach Burnout Manual. Palo Alto: Consulting Psychologists Press.

Maslach C, Jackson SE, Leiter MP (1996) Maslach burnout inventory manual. Palo Alto, Calif: Consulting Psychologists Press.

Maslach CA , Schaufeli WB (1993) Historical and conceptual development of burnout. In Schaufeli WB, Maslach C \& Marek T (Eds), Professional Burnout. Recent Developments in Theory and Research, 1-16. Philadelphia, PA: Taylor \& Francis.

Mavrodiev S, Dimitrova L (2016) Roliata na pedagoga za fotmorane na refleksia pri ucheenitsite (Ot refleksiata na pedagoga kam refleksia u uchenitsite)[The role of the teacher for developing reflection in the students (From the teacher's reflection to the students reflection)]. Strategies for Policy in Science and Education 24 (6): 618-627, Sofia, Bulgaria.

Mavrodiev S (2008) Osnovi na psihologiata [Fundamentals of Psychology], Blagoevgrad, Bulgaria, University Press: Neofit Rilski.

Mills LB, Huebner ES (1998) A prospective study of personality characteristics, occupational stressors, and burnout of school psychology practitioners. Journal of School Psychology 36: 400-405. 
Nasi KH (2018a) Teachers' occupational stress. Yearbook of Psychology 9(1): 115-124, Blagoevgrad, Bulgaria, University Press: Neofit Rilski.

Nasi KH (2018b) Understanding teachers' job satisfaction. Yearbook of Psychology 9(1): 125-135, Blagoevgrad, Bulgaria, University Press: Neofit Rilski.

Pappa B (2006) Teacher stress and factors contributing to burnout syndrome. Review of Educational Issues 11: 135-142.

Parkes KR (1986) Coping in stressful episodes: The role of individual differences, environmental factors, and situational characteristics. Journal of Personality and Social Psychology 51: 1277-1292.

Pajares F, Miller MD (1994) Role of self-efficacy and self-concept beliefs in mathematical problem solving: a path analysis. Journal of Educational psychology 86(2): 193-203.

Pines A, Aronson E, Kafry D (1981) Burnout: From tedium to personal growth. New York: Free Press.

Piedmont RL (1993) A longitudinal analysis of burnout in a health care setting: The role of personal dispositions. Journal of Personality Assessment 61: 457-473.

Pierce CA, Block CA, Aguinis H (2004) Cautionary Note on Reporting Eta-Squared Values Ffrom Multifactor Anova Designs. Educational and Psychological Measurement 64(6).

Schaufeli WB, Leiter MP, Maslach C (2009) Burnout: 35 years of research and practice. Career Development International 14: 204-220.

Schaufeli WB, Enzmann D (1998) The burnout companion to study and practice: A critical analysis. London: Taylor \& Francis.

Skaalvik EM, Skaalvik S (2007) Dimensions of Teacher Self-efficacy and Relations with Strain Factors, Perceived Collective Teacher Efficacy, and Teacher Burnout. Journal of Educational Psychology 99(3): 611-625.

Skaalvik EM, Skaalvik S (2010) Teacher Self-efficacy and Teacher Burnout:A Study of Relations. Teaching and Teacher Education 26(4): 1059-1069.

Skaalvik EM, Skaalvik S (2014) Teacher Self-Efficacy and Perceived Autonomy: Relations with Teacher Engagement, Job Satisfaction, and Emotional Exhaustion. Psychological reports 114(1): 68-77.

Smetackovaa I (2017) Self-efficacy and burnout syndrome among teachers. The European Journal of Social and Behavioural Sciences EJSBS, XX. Retrieved from https://www. futureacademy. org. uk/files/images/upload/ejsbs219.pdf.

Szeliga-Kowalczyk A (2015) Teachers' occupational burn out syndrome in secondary school. Jagiellonian Journal of Management 1(4): 353-367.

Storm K, Rothmann S (2003) The relationship between burnout, personality traits and coping strategies in a corporate pharmaceutical group. Sa Journal of Industrial Psychology 29: 35-42.

Stoyanov D (2012) Personality, psychological climate and burnout syndrome. Manual of Diagnosis and Prevention of Burnout syndrome in health professionals. Sofia: East-West Publishing House.

Stoyanova K, Stoyanov D (2019) Burn out across persons and systems: comparative studies on vulnerability and resilience. European Journal for Person Centered Healthcare 7(2): 410-411.

Stoyanova K (2020) Burnout, Emotional Intelligence and Coping strategies among teachers. Dissertation Abstract. South-West University Neofit Rilski, Blagoevgrad, Bulgaria.

Tsenova B (2005) Lichnostni korelati na burnout sindroma [Personality correlates of burnout syndrome] In Dimitrov et all Eds., 360-367, Publishing House: Sofia-R, http://bjop.files.wordpress.com/2008/10/bistra_tsenova_doklad.pdf. 
Wayne DW (1990) Spearman rank correlation coefficient. Applied Nonparametric Statistics (2nd ed.), 358-365. Boston: PWS-Kent. ISBN 978-0-534-91976-4.

Wright TA, Cropanzano R (1998) Emotional exhaustion as a predictor of job performance and voluntary turnover. Journal of Applied Psychology 83: 486-493.

Zellars KL, Perrewe PL \& Hochwarter WA (2000) Burnout in health care: the role of the five factors of personality. Journal of Applied Social Psychology 30: 1570-1598. 
